\title{
Discovery of investigational drug CT1812, an antagonist of the sigma-2 receptor complex for Alzheimer's Disease
}

\author{
Gilbert M. Rishton, ${ }^{\dagger}$ Gary C. Look,${ }^{\dagger}$ Zhi-Jie Ni,${ }^{\dagger}$ Jason Zhang,${ }^{\dagger}$ Yingcai Wang,${ }^{\dagger}$ Yaodong \\ Huang, ${ }^{\dagger}$ Xiaodong Wu ${ }^{\ddagger}$ Nicholas J. Izzo, ${ }^{\dagger}$ Kelsie M LaBarbera ${ }^{\dagger}$ Colleen S Limegrover,${ }^{\dagger}$ \\ Courtney Rehak, ${ }^{\dagger}$ Raymond Yurko, ${ }^{\dagger}$ Susan M. Catalano* ${ }^{\dagger}$ \\ †Cognition Therapeutics, 2403 Sidney St., Suite 261, Pittsburgh PA, 15203 \\ ${ }^{\ddagger}$ Acme Bioscience, Inc., 3941 E. Bayshore Rd., Palo Alto, CA 94303
}

\section{Supporting Information (40 pages)}

1. General Methods .1

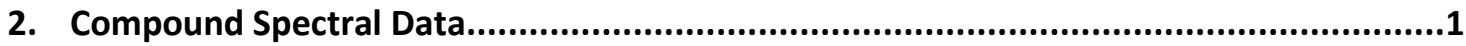

3. Exemplary Experimental for Benzyl-type Compounds ...............................................4

4. Exemplary Experimental for Isoindoline-type Compounds ..........................................5

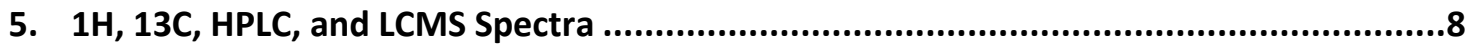

\section{Chemistry - General Methods}

${ }^{1} \mathrm{H}$ and ${ }^{13} \mathrm{C}$ NMR spectra were recorded on a Varian Spectrometer $\left({ }^{1} \mathrm{H} \mathrm{NMR}, 400 \mathrm{MHz} ;{ }^{13} \mathrm{C} \mathrm{NMR}, 100\right.$ $\mathrm{MHz})$ at ambient temperature. Chemical shifts $(\delta)$ are quoted in parts per million (ppm) and are referenced to a residual solvent peak: $\mathrm{CHCl}_{3}-\mathrm{d} 1$ ( $\left.\delta \mathrm{H}: 7.26\right)$, (DMSO-d6 $(\delta \mathrm{H}: 2.50)$, MeOH-d4 ( $\left.\delta \mathrm{H}: 3.31\right)$. Coupling constants $(\mathrm{J})$ are quoted in Hertz $(\mathrm{Hz})$. LC-MS analyses were conducted using a Shimazdu LC-MS 2020 system with UV detection recorded at $220 \mathrm{~nm}$ and $254 \mathrm{~nm}$. Purities of all assayed compounds were $\geq 95 \%$ as determined by LC-MS. HRMS was conducting using an ABSCIEX QSTAR-XL system. All manipulations of air or moisture sensitive materials were carried out in oven- or flame-dried glassware under an inert atmosphere of nitrogen or argon. Syringes, which were used to transfer reagents and solvents, were purged with nitrogen prior to use. Reaction solvents were obtained anhydrous from commercial suppliers. All reagents were obtained from commercial suppliers and used without further purification unless indicated otherwise.

\section{Compound Spectral Data}

2-methoxy-4-(3-((4-(trifluoromethyl)benzyl)amino)butyl)phenol (1)

${ }^{1} \mathrm{H}$ NMR $(400 \mathrm{MHz}$, DMSO-d6) $\delta 8.59(\mathrm{~s}, 1 \mathrm{H}), 7.61(\mathrm{~d}, J=8.1 \mathrm{~Hz}, 2 \mathrm{H}), 7.52(\mathrm{~d}, J=7.9 \mathrm{~Hz}, 2 \mathrm{H}), 6.68(\mathrm{~d}, J=$ $2.0 \mathrm{~Hz}, 1 \mathrm{H}), 6.60(\mathrm{~d}, J=7.9 \mathrm{~Hz}, 1 \mathrm{H}), 6.49(\mathrm{dd}, J=8.0,2.0 \mathrm{~Hz}, 1 \mathrm{H}), 3.84-3.71(\mathrm{~m}, 2 \mathrm{H}), 3.68(\mathrm{~s}, 3 \mathrm{H}), 1.72-$ $1.40(\mathrm{~m}, 2 \mathrm{H}), 0.99(\mathrm{~d}, J=6.2 \mathrm{~Hz}, 3 \mathrm{H})$.

${ }^{13} \mathrm{C}$ NMR $(100 \mathrm{MHz}$, DMSO-d6) $\delta 147.75,147.13,144.73,133.67,128.94,127.49$ (d, q = 31.6 Hz), 125.23, $120.65,115.65,112.82,55.89,55.32,51.64,50.04,31.57,20.48$. 
MS (ESI) $\mathrm{m} / \mathrm{z}$ calcd for $\mathrm{C}_{19} \mathrm{H}_{22} \mathrm{~F}_{3} \mathrm{NO}_{2}(\mathrm{M}+\mathrm{H})^{+}: 354.1682$, found: 354.1679 .

\section{(R)-4-(3,4-dichlorophenyl)-N-(4-(trifluoromethyl)benzyl)butan-2-amine (R-2)}

${ }^{1} \mathrm{H}$ NMR $(400 \mathrm{MHz}$, DMSO-d6) $\delta 9.49(\mathrm{~s}, 1 \mathrm{H}), 7.82(\mathrm{~d}, J=8.1 \mathrm{~Hz}, 1 \mathrm{H}), 7.76(\mathrm{~d}, J=8.1 \mathrm{~Hz}, 1 \mathrm{H}), 7.53-7.50$ $(\mathrm{m}, 1 \mathrm{H}), 7.22$ (dd, $J=8.2,2.0 \mathrm{~Hz}, 1 \mathrm{H}), 4.24(\mathrm{~s}, 1 \mathrm{H}), 2.74$ (ddd, $J=14.7,10.0,5.3 \mathrm{~Hz}, 1 \mathrm{H}), 2.58$ (ddd, $J=$ $13.9,9.5,6.7 \mathrm{~Hz}, 1 \mathrm{H}), 2.19-2.08(\mathrm{~m}, 1 \mathrm{H}), 1.86-1.77(\mathrm{~m}, 1 \mathrm{H}), 1.33(\mathrm{~d}, J=6.4 \mathrm{~Hz}, 2 \mathrm{H})$.

${ }^{13} \mathrm{C}$ NMR $(100 \mathrm{MHz}, \mathrm{DMSO}-d 6) \delta 142.54,137.36,131.37,131.31,130.89,130.83,129.62$ (d, $\left.J=31.8 \mathrm{~Hz}\right)$, $129.31,129.06,125.80$ (q, J = 4.0 Hz), 53.05, 46.73, 33.65, 30.09, 15.92 .

MS (ESI) $\mathrm{m} / \mathrm{z}$ calcd for $\mathrm{C}_{18} \mathrm{H}_{18} \mathrm{Cl}_{2} \mathrm{~F}_{3} \mathrm{~N}(\mathrm{M}+\mathrm{H})^{+}: 376.0849$, found: $376.0843 .[\alpha](\mathrm{MeOH}, \mathrm{c}=1.06)-9.5$.

\section{(S)-4-(3,4-dichlorophenyl)-N-(4-(trifluoromethyl)benzyl)butan-2-amine (S-2)}

${ }^{1} \mathrm{H}$ NMR $(300 \mathrm{MHz}$, DMSO-d6) $\delta 9.59(\mathrm{~s}, 2 \mathrm{H}), 7.84$ (d, $J=7.9 \mathrm{~Hz}, 2 \mathrm{H}), 7.77$ (d, J = 8.2 Hz, 2H), $7.55-7.49$ $(\mathrm{m}, 2 \mathrm{H}), 7.23(\mathrm{dd}, J=8.3,2.0 \mathrm{~Hz}, 1 \mathrm{H}), 4.25(\mathrm{~s}, 2 \mathrm{H}), 3.03(\mathrm{~s}, 1 \mathrm{H}), 2.73(\mathrm{dd}, J=9.6,5.1 \mathrm{~Hz}, 1 \mathrm{H}), 2.61(\mathrm{dd}, J=$ 9.4, $6.5 \mathrm{~Hz}, 1 \mathrm{H}), 2.22-2.06(\mathrm{~m}, 1 \mathrm{H}), 1.91-1.78(\mathrm{~m}, 1 \mathrm{H}), 1.35(\mathrm{~d}, J=6.5 \mathrm{~Hz}, 3 \mathrm{H})$.

${ }^{13} \mathrm{C}$ NMR (100 MHz, DMSO-d6) $\delta 142.55,137.37,131.38,131.32,130.90,130.84,129.63$ (d, J = $\left.31.9 \mathrm{~Hz}\right)$, $129.32,129.07,125.81$ (q, $J=4.0 \mathrm{~Hz}), 53.06,46.74,33.66,30.10,15.93$.

MS (ESI) m/z calcd for $\mathrm{C}_{18} \mathrm{H}_{18} \mathrm{Cl}_{2} \mathrm{~F}_{3} \mathrm{~N}(\mathrm{M}+\mathrm{H})^{+}:$376.0849, found: 376.0861. [ $\alpha$ ] $(\mathrm{MeOH}, \mathrm{c}=1.14)+11.8$.

Rotation of $\mathrm{HCl}$ salt: $[\alpha](\mathrm{MeOH}, \mathrm{c}=1.83)+4.85$.

\section{(R)-4-(4-chlorophenyl)-N-(4-(trifluoromethyl)benzyl)butan-2-amine (3)}

${ }^{1} \mathrm{H}$ NMR (400 MHz, DMSO-d6) $\delta 9.58$ (brs, $\left.1 \mathrm{H}\right), 7.83(\mathrm{~d}, J=8.1 \mathrm{~Hz}, 1 \mathrm{H}), 7.75$ (d, $\left.J=8.1 \mathrm{~Hz}, 1 \mathrm{H}\right), 7.30$ (d, $J=$ $8.4 \mathrm{~Hz}, 1 \mathrm{H}), 7.22(\mathrm{~d}, J=8.4 \mathrm{~Hz}, 1 \mathrm{H}), 4.28-4.16(\mathrm{~m}, 1 \mathrm{H}), 3.02$ (brss, $1 \mathrm{H}), 2.79-2.50(\mathrm{~m}, 2 \mathrm{H}), 2.19-2.09$ $(\mathrm{m}, 1 \mathrm{H}), 1.86-1.74(\mathrm{~m}, 1 \mathrm{H}), 1.33(\mathrm{~d}, J=6.5 \mathrm{~Hz}, 2 \mathrm{H})$.

${ }^{13} \mathrm{C}$ NMR $(100 \mathrm{MHz}$, DMSO-d6) $\delta$ 140.19, 137.35, 131.40, 131.05, 130.62, 129.59 (q, $J=31.7 \mathrm{~Hz}), 128.71$, $125.76(\mathrm{t}, J=3.8 \mathrm{~Hz}), 53.60-51.66(\mathrm{~m}), 46.70,33.88,30.43,15.86$.

MS $[\alpha](\mathrm{MeOH}, \mathrm{c}=2.33)+16.12$.

(ESI) $\mathrm{m} / \mathrm{z}$ calcd for $\mathrm{C}_{18} \mathrm{H}_{19} \mathrm{ClF}_{3} \mathrm{~N}(\mathrm{M}+\mathrm{H})^{+}: 342.1238$, found: 342.1234 .

\section{(R)-2-(4-(3,4-dichlorophenyl)butan-2-yl)-5,6-dimethoxyisoindoline (4)}

${ }^{1} \mathrm{H}$ NMR (400 MHz, DMSO-d6) $\delta 11.87(\mathrm{~s}, 1 \mathrm{H}), 7.58(\mathrm{~d}, J=2.0 \mathrm{~Hz}, 1 \mathrm{H}), 7.55$ (d, $\left.J=8.2 \mathrm{~Hz}, 1 \mathrm{H}\right), 7.28$ (dd, $J=$ 8.2, $2.1 \mathrm{~Hz}, 1 \mathrm{H}), 6.93(\mathrm{~d}, J=5.4 \mathrm{~Hz}, 2 \mathrm{H}), 4.70-4.30(\mathrm{~m}, 4 \mathrm{H}), 3.72(\mathrm{~s}, 6 \mathrm{H}), 2.83-2.55(\mathrm{~m}, 2 \mathrm{H}), 2.17-2.08$ $(\mathrm{m}, 1 \mathrm{H}), 1.91-1.81(\mathrm{~m}, 1 \mathrm{H}), 1.36(\mathrm{~d}, J=6.4 \mathrm{~Hz}, 3 \mathrm{H})$.

${ }^{13} \mathrm{C}$ NMR $(100 \mathrm{MHz}$, DMSO-d6) $\delta$ 149.74, 142.56, 131.36, 130.94, 130.89, 129.34, 126.18, 60.01, 56.17, $56.06,55.80,33.01,30.41,15.24$. 
$[\alpha](\mathrm{MeOH}, \mathrm{c}=1.53)+37.37$.

MS (ESI) m/z calcd for $\mathrm{C}_{20} \mathrm{H}_{23} \mathrm{Cl}_{2} \mathrm{NO}_{2}(\mathrm{M}+\mathrm{H})^{+}: 316.17$, found: 380.25 .

\section{(R)-4-(3-(4-fluoroisoindolin-2-yl)butyl)-2-methoxyphenol (5)}

${ }^{1} \mathrm{H}$ NMR (400 MHz, DMSO-d6) $\delta 8.76(\mathrm{~s}, 1 \mathrm{H}), 7.45-7.32(\mathrm{~m}, 1 \mathrm{H}), 7.20(\mathrm{~d}, \mathrm{~J}=8.2 \mathrm{~Hz}, 2 \mathrm{H}), 6.81(\mathrm{~s}, 1 \mathrm{H})$, $6.75-6.53(\mathrm{~m}, 2 \mathrm{H}), 4.91-4.42(\mathrm{~m}, 4 \mathrm{H}), 3.74(\mathrm{~s}, 3 \mathrm{H}), 3.49(\mathrm{~s}, 1 \mathrm{H}), 2.64(\mathrm{dt}, \mathrm{J}=10.3,4.4 \mathrm{~Hz}, 1 \mathrm{H}), 2.17$ (brs, 1H), 1.84 (brs, 1H), 1.38 (s, 1H). ${ }^{13} \mathrm{C}$ NMR (101 MHz, DMSO-d6) $\delta 158.25,155.79,147.93,145.21,138.49$ (d, J = 4.9 Hz), 131.56 (d, J = 7.0 Hz), $121.52(d, J=17.8 \mathrm{~Hz}), 120.86,119.46$ (d, J = 3.5 Hz), 115.78, 115.41 $(d, J=19.1 \mathrm{~Hz}), 112.96,60.43,56.03,55.92(d, J=37.3 \mathrm{~Hz}), 52.86(d, J=29.1 \mathrm{~Hz}), 33.53(d, J=20.5 \mathrm{~Hz})$, $31.09,15.20$.

$[\alpha](\mathrm{MeOH}, \mathrm{c}=2.93)+11.67 . \mathrm{MS}(\mathrm{ESI}) \mathrm{m} / \mathrm{z}$ calcd for $\mathrm{C}_{19} \mathrm{H}_{22} \mathrm{FNO}_{2}(\mathrm{M}+\mathrm{H})^{+}: 380.12$, found: 316.30 .

\section{4-(3-(4-fluoroisoindolin-2-yl)-3-methylbutyl)-2-isopropoxyphenol (6)}

${ }^{1} \mathrm{H}$ NMR (400 MHz, DMSO-d6) $\delta 12.34(\mathrm{~s}, 1 \mathrm{H}), 8.60(\mathrm{~s}, 1 \mathrm{H}), 7.40(\mathrm{t}, J=4.1 \mathrm{~Hz}, 1 \mathrm{H}), 7.25-7.13(\mathrm{~m}, 2 \mathrm{H})$, $6.93-6.53(\mathrm{~m}, 3 \mathrm{H}), 4.97-4.36(\mathrm{~m}, 6 \mathrm{H}), 2.68-2.35(\mathrm{~m}, 3 \mathrm{H}), 2.09-1.85(\mathrm{~m}, 2 \mathrm{H}), 1.57-1.31(\mathrm{~m}, 6 \mathrm{H})$, $1.21(\mathrm{~d}, J=6.0 \mathrm{~Hz}, 6 \mathrm{H})$.

${ }^{13} \mathrm{C}$ NMR (100 MHz, DMSO-d6) $\delta 157.15$ (d, J = 247.2 Hz), 155.92, 146.68, 145.57, 138.23 (d, $J=4.6 \mathrm{~Hz}$ ), $132.19,131.44$ (d, $J=7.0 \mathrm{~Hz}$ ), 121.59, 121.37 (d, $J=17.8 \mathrm{~Hz}), 119.45,117.54,116.16,115.26$ (d, $J=18.8$ $\mathrm{Hz}), 71.20,64.82,55.37,52.82,49.87,29.67,22.46,21.63$ (d, $J=6.5 \mathrm{~Hz}$ ).

MS (ESI) $\mathrm{m} / \mathrm{z}$ calcd for $\mathrm{C}_{22} \mathrm{H}_{28} \mathrm{FNO}_{2}(\mathrm{M}+\mathrm{H})^{+}: 358.2184$, found: 358.2180 .

\section{2-(tert-butoxy)-4-(3-methyl-3-(5-(methylsulfonyl)isoindolin-2-yl)butyl)phenol (7)}

${ }^{1} \mathrm{H}$ NMR $(400 \mathrm{MHz}, \mathrm{DMSO}-\mathrm{d} 6) \delta 8.41(\mathrm{~s}, 1 \mathrm{H}), 7.76(\mathrm{~d}, J=1.7 \mathrm{~Hz}, 1 \mathrm{H}), 7.72(\mathrm{dd}, J=7.9,1.7 \mathrm{~Hz}, 1 \mathrm{H}), 7.47$ (d, $J=7.9 \mathrm{~Hz}, 1 \mathrm{H}), 6.75-6.68(\mathrm{~m}, 3 \mathrm{H}), 4.00(\mathrm{~s}, 4 \mathrm{H}), 3.13(\mathrm{~s}, 3 \mathrm{H}), 1.68-1.57(\mathrm{~m}, 3 \mathrm{H}), 1.24(\mathrm{~s}, 9 \mathrm{H}), 1.06(\mathrm{~s}$, $6 \mathrm{H})$.

${ }^{13} \mathrm{C}$ NMR $(100 \mathrm{MHz}$, DMSO-d6) $\delta$ 149.52, 146.56, 142.48, 141.80, 139.68, 133.59, 126.03, 125.40, 124.02, 123.69, 121.56, 116.53, 79.35, 54.81, 51.52, 51,29, 44.22, 43.53, 29.39, 28.80, 22.78.

MS (ESI) $\mathrm{m} / \mathrm{z}$ calcd for $\mathrm{C}_{24} \mathrm{H}_{33} \mathrm{NO}_{4} \mathrm{~S}(\mathrm{M}+\mathrm{H})^{+}:$: 432.221, found: 432.2216 . 


\section{Synthetic Examples}

The compounds provided herein can be synthesized via any synthetic route; for example, see WO2013/029060, and WO2013/029067, each of which is incorporated herein by reference.

Exemplary Synthesis of benzyl -type compounds:

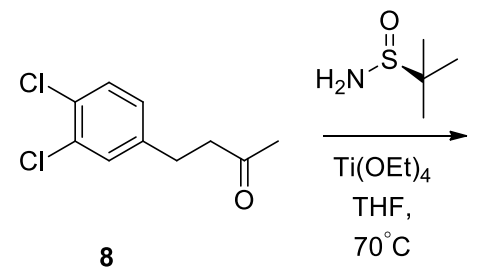

8

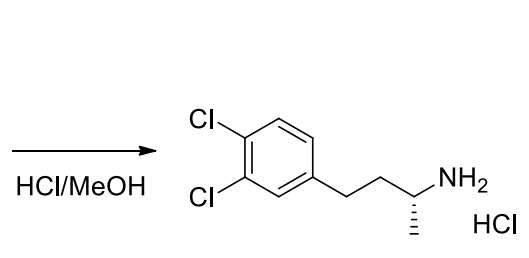

12
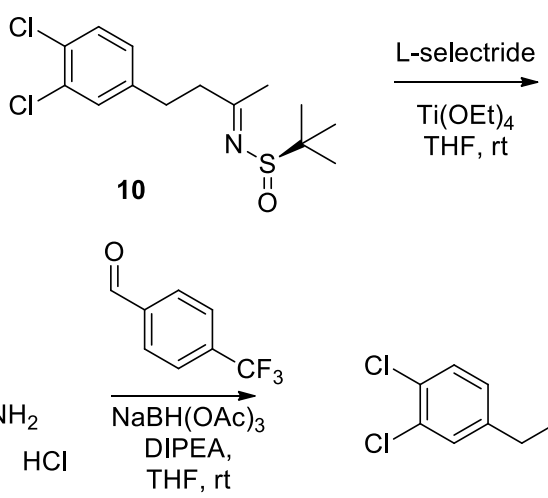

THF, rt

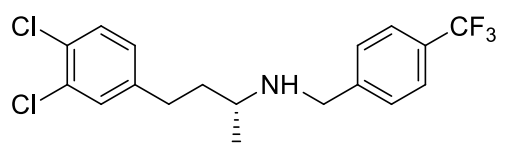

(R)-2

Scheme 1. Procedure for preparation of 2 (R)-4-(3,4-dichlorophenyl)-N-(4(trifluoromethyl)benzyl)butan-2-amine, Compound (R)-2 free base.

Preparation of Compound 10: To a solution of $8(10 \mathrm{~g}, 46 \mathrm{mmol})$ in THF $(100 \mathrm{~mL})$ was added Ti(OEt $)_{4}(21$ $\mathrm{g}, 92 \mathrm{mmol})$, and (S)-(-)-tert-butylsulfinamide $(6.1 \mathrm{~g}, 50 \mathrm{mmol})$. The mixture was stirred at $70^{\circ} \mathrm{C}$ for $12 \mathrm{~h}$, quenched by ice water, extracted with ethyl acetate $(3 \times 250 \mathrm{~mL})$. After being concentrated by vacuum, the crude product was purified by column chromatography (PE/EA:10/1) to afford compound 10 ( $8.1 \mathrm{~g}$, $55 \%)$.

Preparation of Compound T: To a solution of compound $10(3.3 \mathrm{~g}, 10 \mathrm{mmol})$ in THF $(30 \mathrm{~mL})$ was added L-Selectride $\left(33 \mathrm{~mL}, 1.0 \mathrm{M}\right.$ in THF, $33 \mathrm{mmol}$ ) at $0^{\circ} \mathrm{C}$. The reaction was allowed to warm to rt over a $3 \mathrm{~h}$ period. Analysis of the reaction mixture by TLC showed complete consumption of the starting imine 4. The solution was quenched by water and extracted by ethyl acetate $(3 \times 30 \mathrm{~mL})$. The combined organic layer was washed with brine, dried over $\mathrm{Na}_{2} \mathrm{SO}_{4}$ and concentrated under vacuum to give a residue, which was purified by column chromatography (PE/EA:2/1) to provide product $\mathrm{T}(0.9 \mathrm{~g}, 27 \%)$.

Preparation of Compound 12: To a solution of compound T (5 g, $15.5 \mathrm{mmol})$ in $\mathrm{MeOH}(10 \mathrm{~mL}), \mathrm{HCl}(2 \mathrm{M}$ in $\mathrm{MeOH}, 10 \mathrm{~mL}$ ) was added and the resulting solution was stirred at rt for $3 \mathrm{~h}$. TLC analysis of the reaction mixture showed complete consumption of compound 12 . The solvent was removed in vacuum, and the crude 6 (3.95 g, 100\%) was used directly for next step without further purification.

Preparation of Compound (R)-2: To a solution of $12(0.6 \mathrm{~g}, 2.4 \mathrm{mmol})$ in THF (10 mL), DIPEA (0.4 g, 3.1 $\mathrm{mmol}$ ) and 3-trifluoromethylbenzaldehyde $(0.41 \mathrm{~g}, 2.4 \mathrm{mmol})$ were added subsequently. The resulting solution was stirred at $r \mathrm{t}$ for $10 \mathrm{~min}$. $\mathrm{NaBH}(\mathrm{OAc})_{3}(1.0 \mathrm{~g}, 4.7 \mathrm{mmol})$ was added and the mixture was 
stirred for $12 \mathrm{~h}$. The mixture was quenched by water at $0^{\circ} \mathrm{C}$ filtered and extracted by EtOAc $(3 \times 30 \mathrm{~mL})$. The organic layer was washed by brine, dried over sodium sulfate, filtered and the filtrate was concentrated under reduced pressure to afford a residue. The residue was purified by column chromatography (PE/EA $=1: 1)$ to give compound $(R)-2(0.4 \mathrm{~g}, 45 \%)$.

\section{Exemplary Synthesis of Isoindoline-type compounds:}
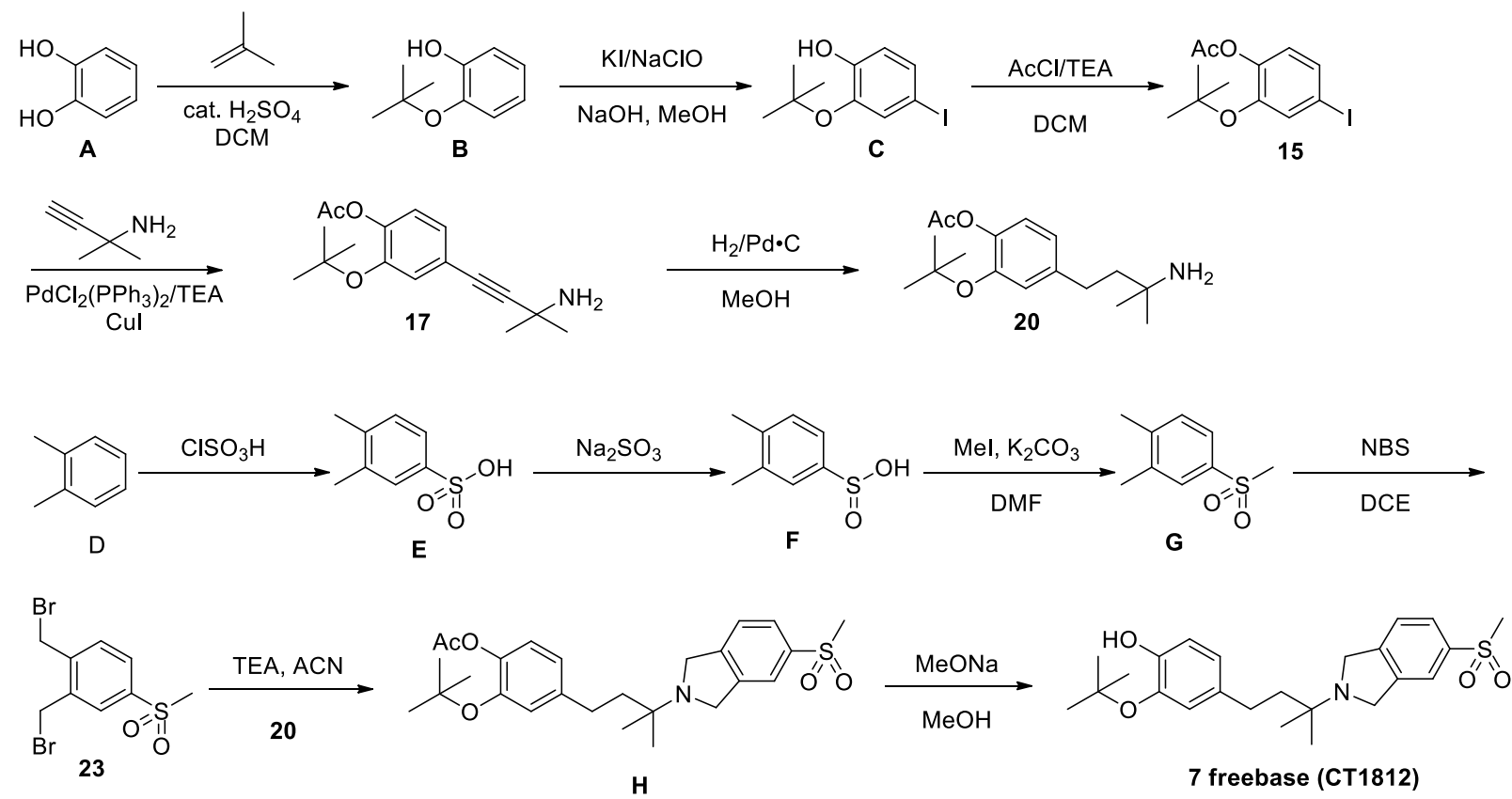

Scheme 2. Procedure for preparation of 2-(Tert-butoxy)-4-(3-methyl-3-(5-(methylsulfonyl)isoindolin-2yl)butyl)phenol, Compound 7 free base (CT1812).

Preparation of compound B: To a glass pressure-bottle at $-30{ }^{\circ} \mathrm{C}$ containing a mixture of catechol (A) $(50.0$ g, $454 \mathrm{mmol}, 1.0 \mathrm{eq})$, concentrated sulfuric acid $(0.3 \mathrm{~mL})$ in dichloromethane $(200 \mathrm{~mL})$, isobutene $(152.6$ g, $2.72 \mathrm{~mol}, 6.0 \mathrm{eq}$ ) was condensed. After sealing the pressure-bottle with a threaded Teflon cap tipped with a Teflon-protected rubber O-ring, the mixture was heated at $35^{\circ} \mathrm{C}$ for $3 \mathrm{~h}$ until a clear solution was obtained. After cooling $\left(-30^{\circ} \mathrm{C}\right)$, triethylamine $(1.5 \mathrm{~mL}, 10.8 \mathrm{mmol})$ was added and the mixture was concentrated. The residue was suspended in $0.5 \mathrm{M} \mathrm{NaOH}(1 \mathrm{~L})$ and stirred for $10 \mathrm{~min}$. The dark-green colored solution was washed with petroleum ether $(2 \times 100 \mathrm{~mL})$ and the washing layers were reextracted with $0.5 \mathrm{M} \mathrm{NaOH}(3 \times 100 \mathrm{~mL})$. The combined aqueous layers were brought to $\mathrm{pH} 7-8$ with $2 \mathrm{~N} \mathrm{HCl}(400$ $\mathrm{mL})$, and extracted with ethyl acetate $(2 \times 1 \mathrm{~L})$, dried over sodium sulfate and concentrated to afford product $B(67.7 \mathrm{~g}, 90 \%)$ as a colorless oil, which was used directly for the next step reaction without further purification. TLC: PE/EA = 50/1; $\operatorname{Rf}($ Catechol $A)=0.1 ; \operatorname{Rf}($ Compound $B)=0.6$.

Preparation of compound C: To a stirred solution of compound B (112.2 g, $676 \mathrm{mmol}, 1.2 \mathrm{eq})$ and potassium iodide $(112.2 \mathrm{~g}, 676 \mathrm{mmol}, 1.0 \mathrm{eq})$ in methanol $(2 \mathrm{~L})$ at $0^{\circ} \mathrm{C}$ was slowly added sodium hydroxide $(27.0 \mathrm{~g}, 676 \mathrm{mmol}, 1.0 \mathrm{eq})$, followed with aqueous sodium chlorite ( $7 \%$ aq., $718.8 \mathrm{~mL}, 710 \mathrm{mmol}, 1.05 \mathrm{eq})$ dropwise over $3 \mathrm{~h}$ while keeping the reaction below $0{ }^{\circ} \mathrm{C}$. The mixture was stirred at $0{ }^{\circ} \mathrm{C}$ for another 30 
min and neutralized by adding $2 \mathrm{~N} \mathrm{HCl}$ at $0^{\circ} \mathrm{C}$ till $\mathrm{pH} 7$, extracted with $\mathrm{DCM}(2 \times 1 \mathrm{~L})$. The organic layers were dried over sodium sulfate and concentrated to afford product $C$ (179.8 g, 91\%). TLC: PE/EA = 50/1; $\mathrm{Rf}($ Compound $\mathrm{B})=0.6 ; \mathrm{Rf}($ Compound $\mathrm{C})=0.6$.

Preparation of compound 15: To a stirred solution of compound C (179.8 g, $616 \mathrm{mmol}, 1.0 \mathrm{eq})$ and triethylamine $(186.6 \mathrm{~g}, 1.85 \mathrm{~mol}, 3.0 \mathrm{eq})$ in dichloromethane $(2 \mathrm{~L})$ at $0^{\circ} \mathrm{C}$ was slowly added acetyl chloride $(53.2 \mathrm{~g}, 677 \mathrm{mmol}, 1.1 \mathrm{eq})$. The mixture was stirred at $0^{\circ} \mathrm{C}$ for another $30 \mathrm{~min}$, and warmed up to rt, and stirred at $\mathrm{rt}$ for $3 \mathrm{~h}$, water $(1 \mathrm{~L})$ was added into the reaction mixture and the organic layer was washed with brine, dried over sodium sulfate and concentrated to afford product 15 (206 g, 100\%), which was used directly to the next step without further purification. TLC: PE/EA = 50/1; Rf (Compound C) = 0.6; Rf (Compound 15) $=0.5$.

Preparation of compound 17: To a stirred solution of compound 15 (206 g, $616 \mathrm{mmol}, 1.0 \mathrm{eq}$ ) in triethylamine (4.0 L) was added 2-methylbut-3-yn-2-amine (102.5 g, $1.23 \mathrm{~mol}, 2.0 \mathrm{eq}), \mathrm{Pd}(\mathrm{PPh} 3)_{2} \mathrm{Cl}_{2}(15.1$ $\mathrm{g}, 18.5 \mathrm{mmol}, 0.03 \mathrm{eq})$ and copper $(\mathrm{l})$ iodide $(5.9 \mathrm{~g}, 31 \mathrm{mmol}, 0.05 \mathrm{eq})$ and resulting mixture was stirred at $\mathrm{rt}$ for $17 \mathrm{~h}$. The solvent was removed under reduced pressure and the crude product was purified by silica gel chromatography to afford the title compound 17 (132.7 g, 74\%). TLC: PE/EA = 1/1; Rf (Compound 15) =0.9; $\operatorname{Rf}($ Compound 17) $=0.3$.

Preparation of compound 20: To a stirred solution of compound 17 ( $104.5 \mathrm{~g}, 0.36 \mathrm{~mol})$ in ethanol (1.5 L) was added $\mathrm{Pd} / \mathrm{C}(10 \% \mathrm{wt}, 10.5 \mathrm{~g})$. The mixture was stirred under hydrogen (balloon) overnight, and filtered. The filtrate was evaporated to dryness to afford compound 20 (106.3 g, 100\%), which was used directly to the next step without further purification. TLC: PE/EA = 1/1; Rf (Compound 17) = 0.3; Rf (Compound 20) $=0.3$.

Preparation of compound E: To a solution of o-xylene D (115.7 g, $1.09 \mathrm{~mol}, 1.0 \mathrm{eq})$ in chloroform (1.0 L) at $0^{\circ} \mathrm{C}$ was added $\mathrm{ClSO}_{3} \mathrm{H}(254 \mathrm{~g}, 2.18 \mathrm{~mol}, 2.0 \mathrm{eq})$ dropwise. After the addition, the reaction mixture was stirred at room temperature for 2 days, and poured into ice. The crude mixture was extracted with dichloromethane $(3 \times 1.0 \mathrm{~L})$. The organic layers were combined, dried over anhydrous sodium sulfate, concentrated to afford the crude compound $E(161.5 \mathrm{~g}, 80 \%)$ as a white solid, which was used directly to the next step without further purification. TLC: $P E / E A=5 / 1 ; \operatorname{Rf}($ Compound $E)=0.7$.

General procedure for the preparation of compound F: To a stirred solution of compound $\mathrm{E}(161.5 \mathrm{~g}, 0.87$ mol, $1.0 \mathrm{eq}$ ) in saturated sodium sulfite solution ( $273 \mathrm{~g}, 2.17 \mathrm{~mol}, 2.5 \mathrm{eq}$, in $2.0 \mathrm{~L}$ of water) was added dropwise $32 \% \mathrm{NaOH}(69.4 \mathrm{~g}, 1.73 \mathrm{~mol}, 2.0 \mathrm{eq})$ till the solution reached $\mathrm{pH}$ 9. After stirring at rt overnight, the reaction mixture was acidified with conc. $\mathrm{HCl}$ in ice-cooling bath till $\mathrm{pH} 1$. The precipitate was filtered, and washed with ice-water ( $2 x)$, dried in vacuo to afford the crude product $F(131 \mathrm{~g}, 88 \%)$, which was used directly for next step without further purification. TLC: $P E / E A=5 / 1 ; \operatorname{Rf}($ Compound E) =0.7; $\operatorname{Rf}$ (Compound F) $=0.6$.

Preparation of compound G: To a stirred solution of compound $\mathrm{F}(130 \mathrm{~g}, 0.76 \mathrm{~mol}, 1.0 \mathrm{eq}$ ) and potassium carbonate $(211 \mathrm{~g}, 1.53 \mathrm{~mol}, 2.0 \mathrm{eq})$ in DMF $(300 \mathrm{~mL}$ ) was added iodomethane ( $96 \mathrm{~mL}, 1.53 \mathrm{~mol}, 2.0 \mathrm{eq})$. The reaction was stirred at $40^{\circ} \mathrm{C}$ overnight. The reaction mixture was evaporated to dryness, extracted 
with ethyl acetate. The organic layers were washed with water and brine, dried over sodium sulfate and concentrated, purified by flash column chromatography (PE: EA,10: 1 5:1) to afford compound G (85.2 g, 61\%). TLC: PE/EA = 5/1; Rf (Compound F) = 0.6; Rf (Compound G) = 0.3.

Preparation of compound 23: To a stirred solution of compound G (78.2 g, $424 \mathrm{mmol}, 1.0 \mathrm{eq})$ in 1,2dichloroethane (1.2 L), were added N-bromosuccinimide (166 g, $934 \mathrm{mmol}, 2.2 \mathrm{eq}$ ) and AIBN (6.9 g, 42.4 mmol, 0.1 eq). The reaction was stirred at reflux overnight. The reaction was diluted with water and dichloromethane. The organic layer was collected, and dried over sodium sulfate and concentrated, purified by flash column chromatography to afford compound 23 , which was further recrystallized from hot methanol to afford the pure product 23 (75 g, 52\%). TLC: PE/EA = 5/1; Rf (Compound G) = 0.3; Rf (Compound 23) $=0.2$.

Preparation of compound H: To a stirred solution of compound 20 (46 g, $157 \mathrm{mmol}, 1.0 \mathrm{eq})$ and compound 23 (53.5 g, $157 \mathrm{mmol}, 1.0 \mathrm{eq})$ in THF ( $460 \mathrm{~mL}$ ) was added triethylamine $(47.7 \mathrm{~g}, 472 \mathrm{mmol}, 3.0$ eq). The reaction was stirred at $40^{\circ} \mathrm{C}$ overnight, filtered and the filtrate was evaporated to dryness and purified by flash column chromatography to afford compound H (45 g, 63\%). TLC: PE/EA = 1/1; Rf $($ Compound 20$)=0.3 ; \operatorname{Rf}($ Compound 23$)=1.0 ; \operatorname{Rf}($ Compound $H)=0.4$.

Preparation of Compound 7 (CT1812): To a stirred solution of compound H (45 g, $98.4 \mathrm{mmol}$ ) in methanol $(300 \mathrm{~mL}$ ) was added sodium methoxide $(844 \mathrm{mg}, 15.6 \mathrm{mmol}, 0.16 \mathrm{eq})$ in one portion. The solution was stirred at rt overnight. Water $(250 \mathrm{~mL})$ was added dropwise into the reaction mixture over $1 \mathrm{~h}$, the mixture was stirred at $\mathrm{rt}$ for $2 \mathrm{~h}$, and filtered. The white solid was collected and dried on vacuum overnight to afford pure example Compound 7 free base ( $38 \mathrm{~g}, 89 \%)$. TLC: PE/EA = 1/1; Rf (Compound $H$ ) $=0.4 ; \mathrm{Rf}($ Compound 7) = 0.4; $1 \mathrm{H} \mathrm{NMR} \mathrm{(400} \mathrm{MHz,} \mathrm{CDCl3)} \mathrm{\delta} \mathrm{7.80-7.78} \mathrm{(m,} \mathrm{2H).} \mathrm{7.40-7.38} \mathrm{(m,} \mathrm{1H),} \mathrm{6.87-}$ $6.79(\mathrm{~m}, 3 \mathrm{H}), 5.58(\mathrm{~s}, 1 \mathrm{H}), 4.11(\mathrm{~s}, 4 \mathrm{H}), 3.05(\mathrm{~s}, 3 \mathrm{H}), 2.61-2.57(\mathrm{~m}, 2 \mathrm{H}), 1.76-1.72(\mathrm{~m}, 2 \mathrm{H}), 1.48(\mathrm{~s}, 9 \mathrm{H})$, $1.18(\mathrm{~s}, 6 \mathrm{H})$. MS (ESI) $\mathrm{m} / \mathrm{z}$ calcd for $\mathrm{C}_{24} \mathrm{H}_{33} \mathrm{NO}_{4} \mathrm{~S}(\mathrm{M}+\mathrm{H})^{+}: 432.221$, found: 432.2216 . 


\section{${ }^{1} \mathrm{HNMR},{ }^{13} \mathrm{CNMR}$ and HPLC Spectra of Compounds}

\section{Compound 1}

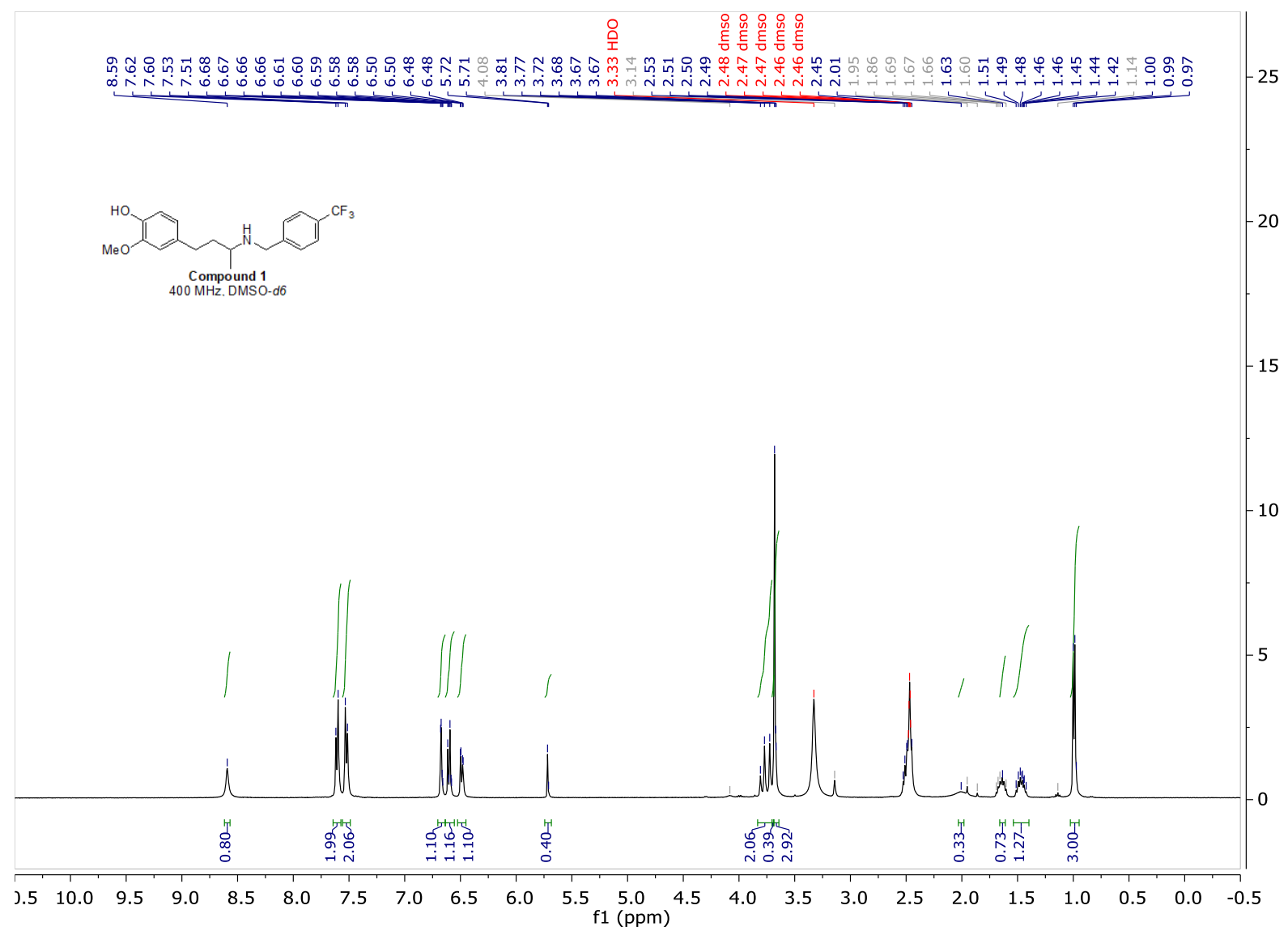




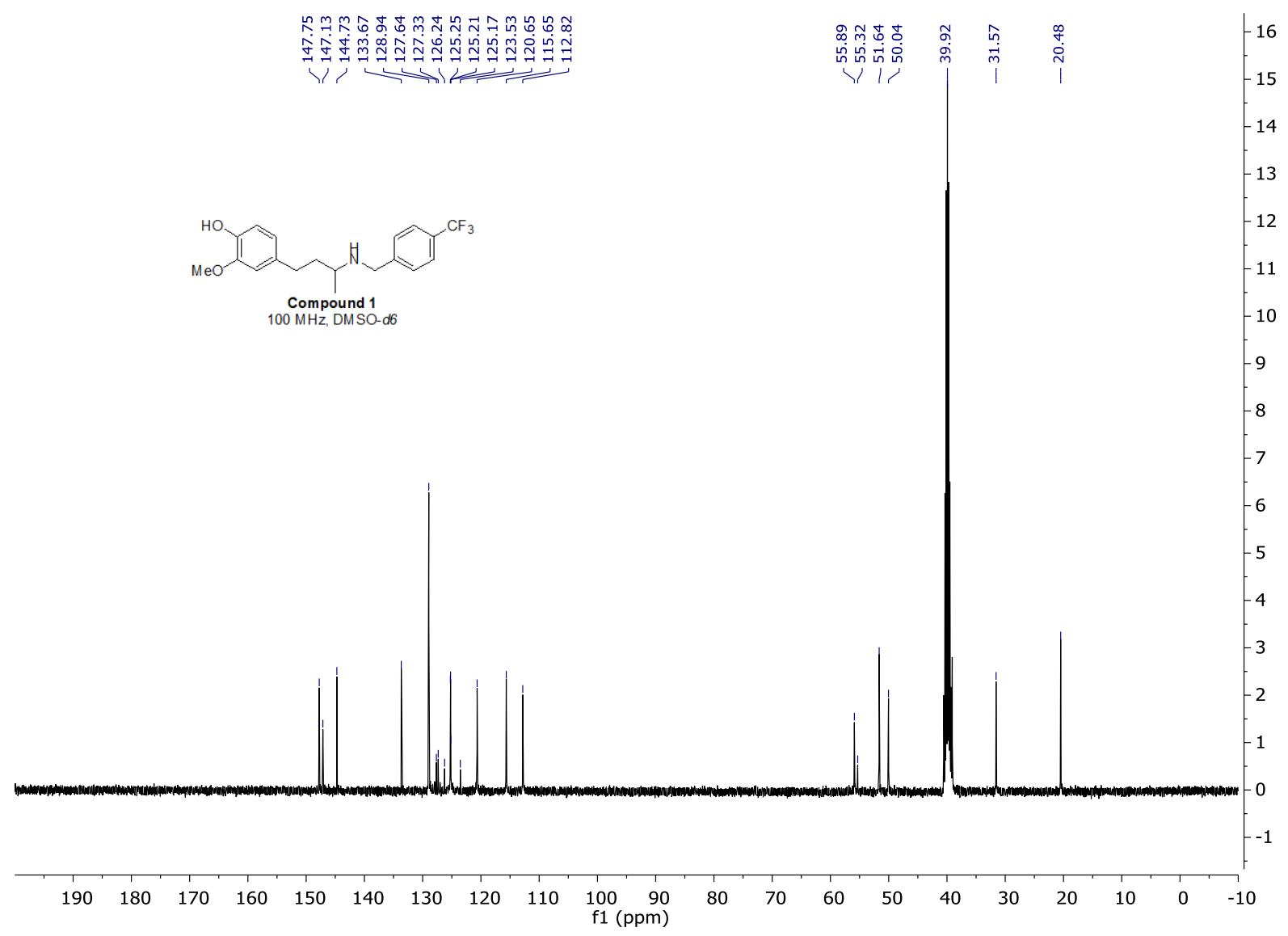




\section{Acme Bioscience, Inc. \\ LC-MS Report}

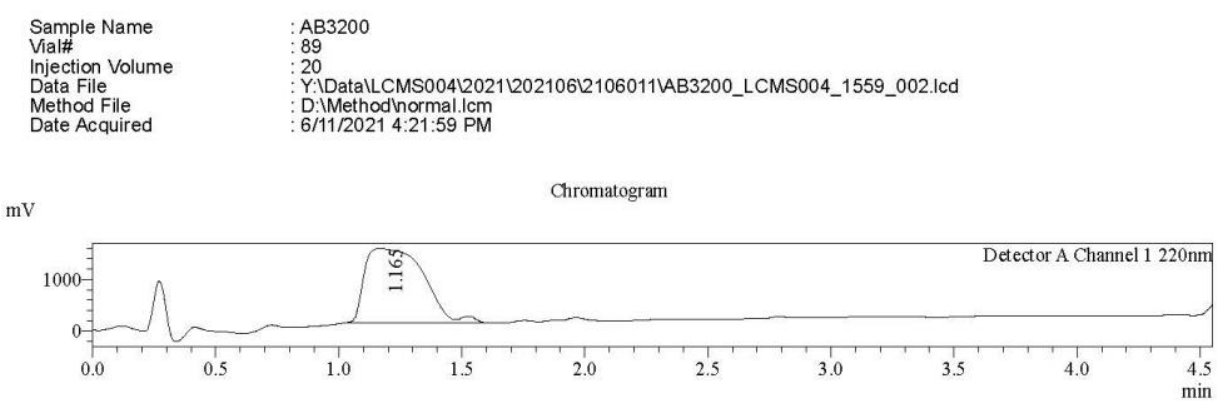

$\mathrm{mV}$

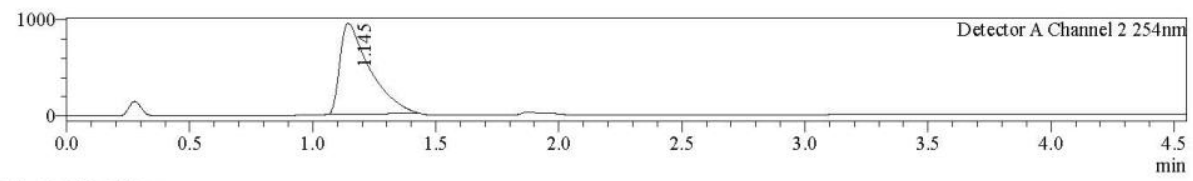

1 Det.A Ch1 $/ 220 \mathrm{~nm}$
2 Det.A Ch2 / $254 \mathrm{~nm}$
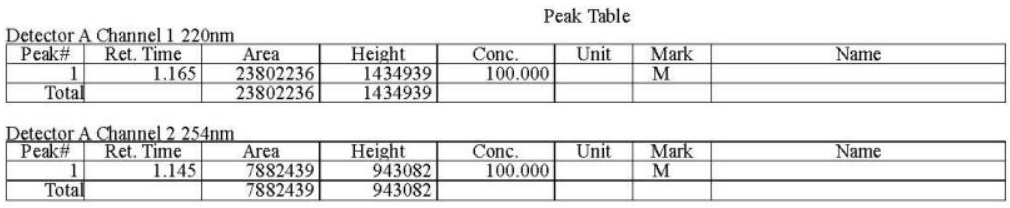

\begin{tabular}{|r|r|r|r|r|r|r|r|}
\hline 1 & 1.145 & 7882439 & 943082 & 100.000 & & M & \\
\hline Total & & 7882439 & 943082 & & & & \\
\hline
\end{tabular}

Line\#:1 R.Time:1.200(Scan\#:73)

MS Spectrum Graph

MassPeaks:959

Spectrum Mode:Single 1.200(73) BasePeak:354.30(4323523)

BG Mode: None Segment 1 - Event 1

ESI Positive

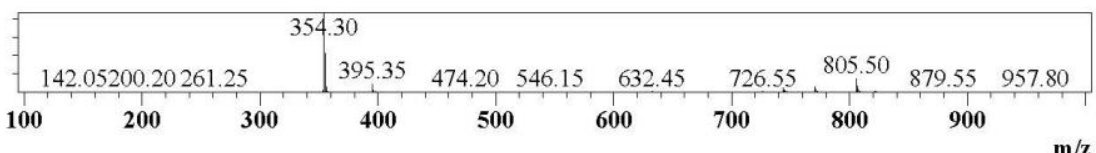

Line\#:2 R.Time:1.216(Scan\#:74)

MassPeaks:1030

BG Mode: None Segment 1 - Event 2

ESI Negative

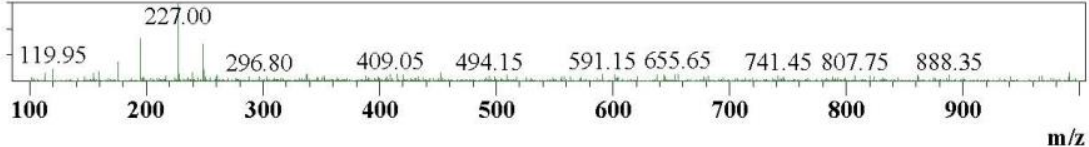


Data File Y: \DATA \HPLC-4 (71) \2021 $202106 \backslash 210611 \backslash$ AB3200.D Sample Name: $A B 3200$

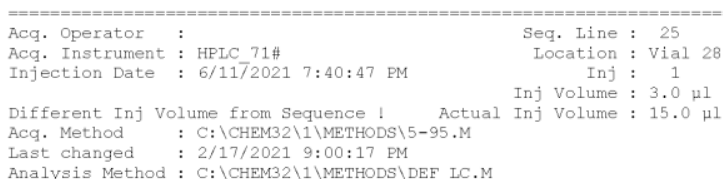

Last changed : 2/17/2021 9:00:17 PM

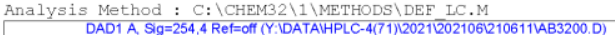
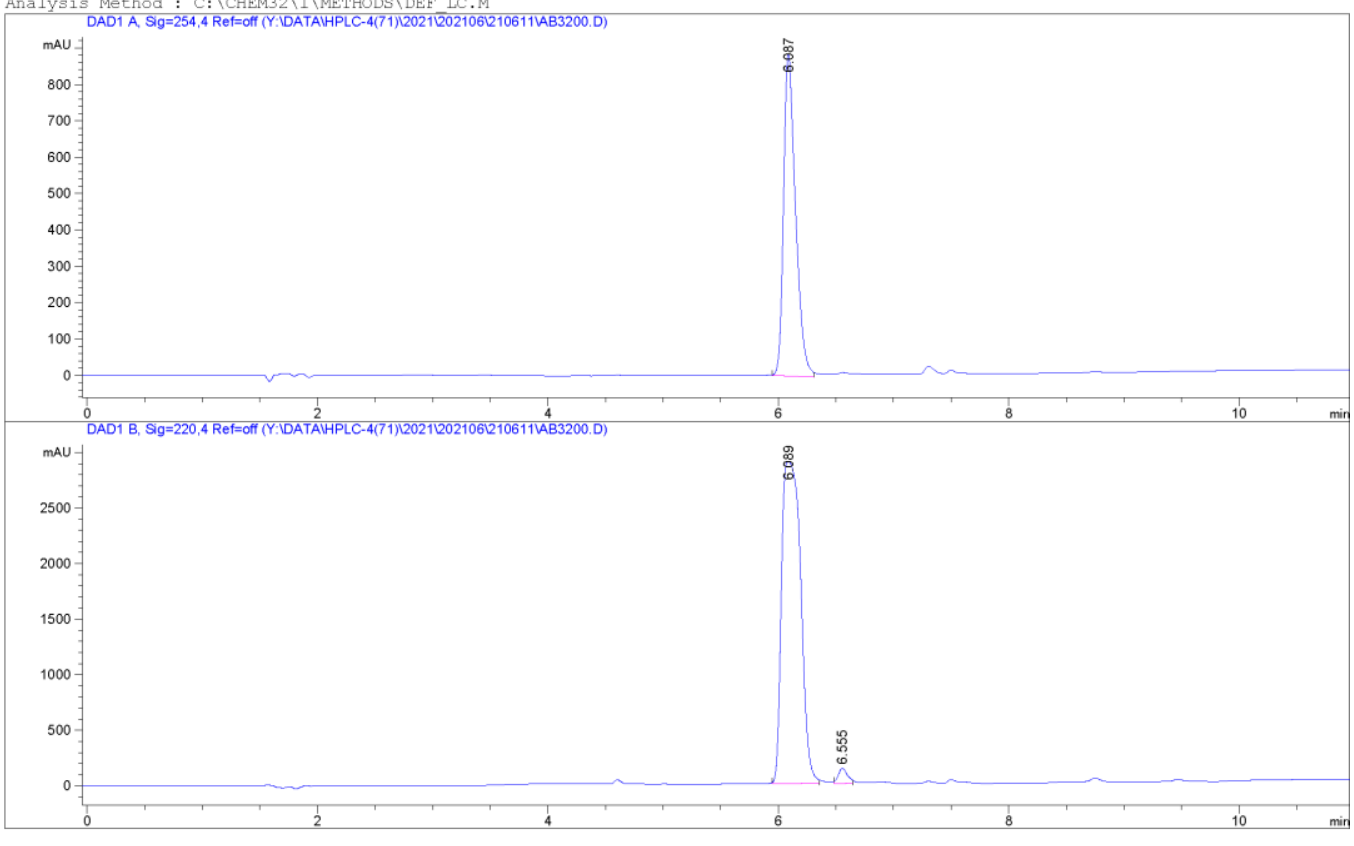

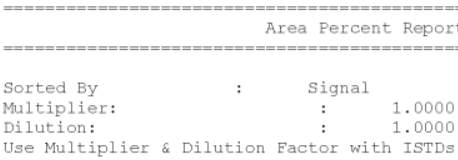

Signal 1: DAD1 A, Sig=254,4 Ref=off

\begin{tabular}{|c|c|c|c|c|c|}
\hline $\begin{array}{c}\text { Peak } \\
\#\end{array}$ & $\begin{array}{l}\text { RetTime Type } \\
\text { [min] }\end{array}$ & $\begin{array}{l}\text { Width } \\
\text { [min] }\end{array}$ & $\begin{array}{c}\text { Area } \\
{[\mathrm{mAU} * \mathrm{~s}]}\end{array}$ & $\begin{array}{l}\text { Height } \\
\text { [mAU] }\end{array}$ & $\begin{array}{c}\text { Area } \\
8\end{array}$ \\
\hline 1 & $6.087 \mathrm{MM} \mathrm{R}$ & 0.1191 & 6347.31592 & 888.28058 & 100.0000 \\
\hline
\end{tabular}

Totals : $6347.31592 \quad 888.28058$

Signal 2: DAD1 B, Sig=220, 4 Ref $=$ off

\begin{tabular}{|c|c|c|c|c|c|c|}
\hline $\begin{array}{c}\text { Peak } \\
\#\end{array}$ & $\begin{array}{l}\text { RetTime } \\
\text { [min] }\end{array}$ & Type & $\begin{array}{c}\text { Width } \\
\text { [min] }\end{array}$ & $\begin{array}{c}\text { Area } \\
{\left[\mathrm{mAU} \mathbf{U}^{*} \mathrm{~s}\right]}\end{array}$ & $\begin{array}{l}\text { Height } \\
\text { [mAU] }\end{array}$ & $\begin{array}{c}\text { Area } \\
\frac{8}{8}\end{array}$ \\
\hline 2 & $\begin{array}{l}6.089 \\
6.555\end{array}$ & MM R & $\begin{array}{l}0.1903 \\
0.0915\end{array}$ & $\begin{array}{c}3.31552 \mathrm{e} \\
758.89111\end{array}$ & $\begin{array}{r}2903.33740 \\
138.16972\end{array}$ & $\begin{array}{r}97.7623 \\
2.2377\end{array}$ \\
\hline
\end{tabular}

Totals :

$3.39141 \mathrm{e} \quad 3041.50713$

$* *$ End of Report *** 


\section{Compound R-2}

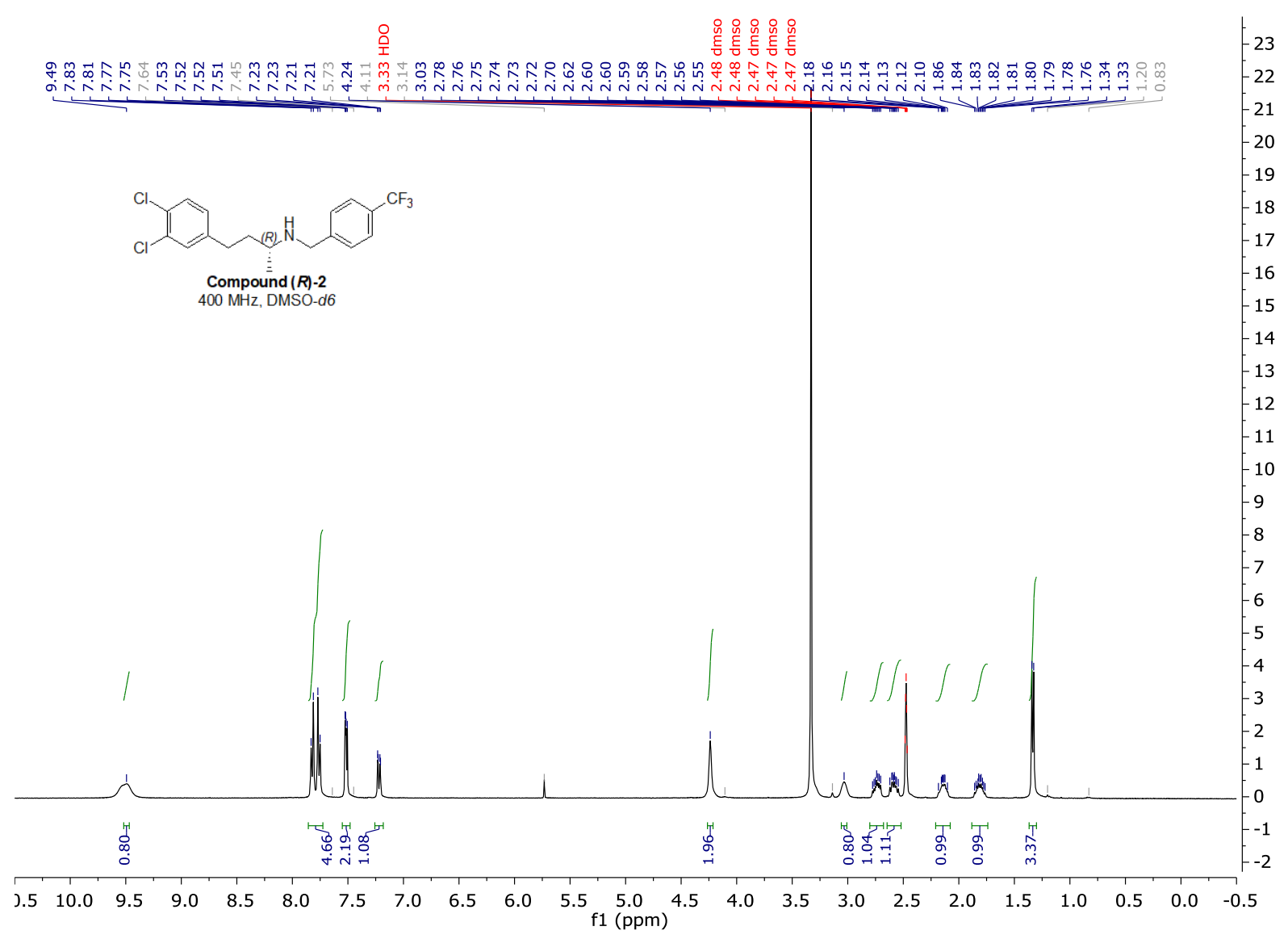




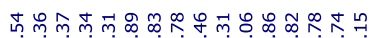

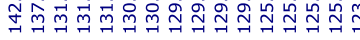

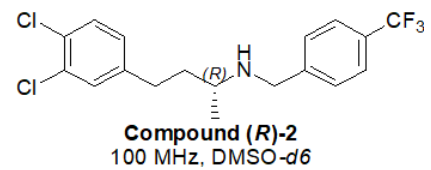

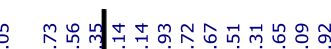

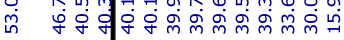

$100 \mathrm{MHz}, \mathrm{DMSO}-\mathrm{d} 6$

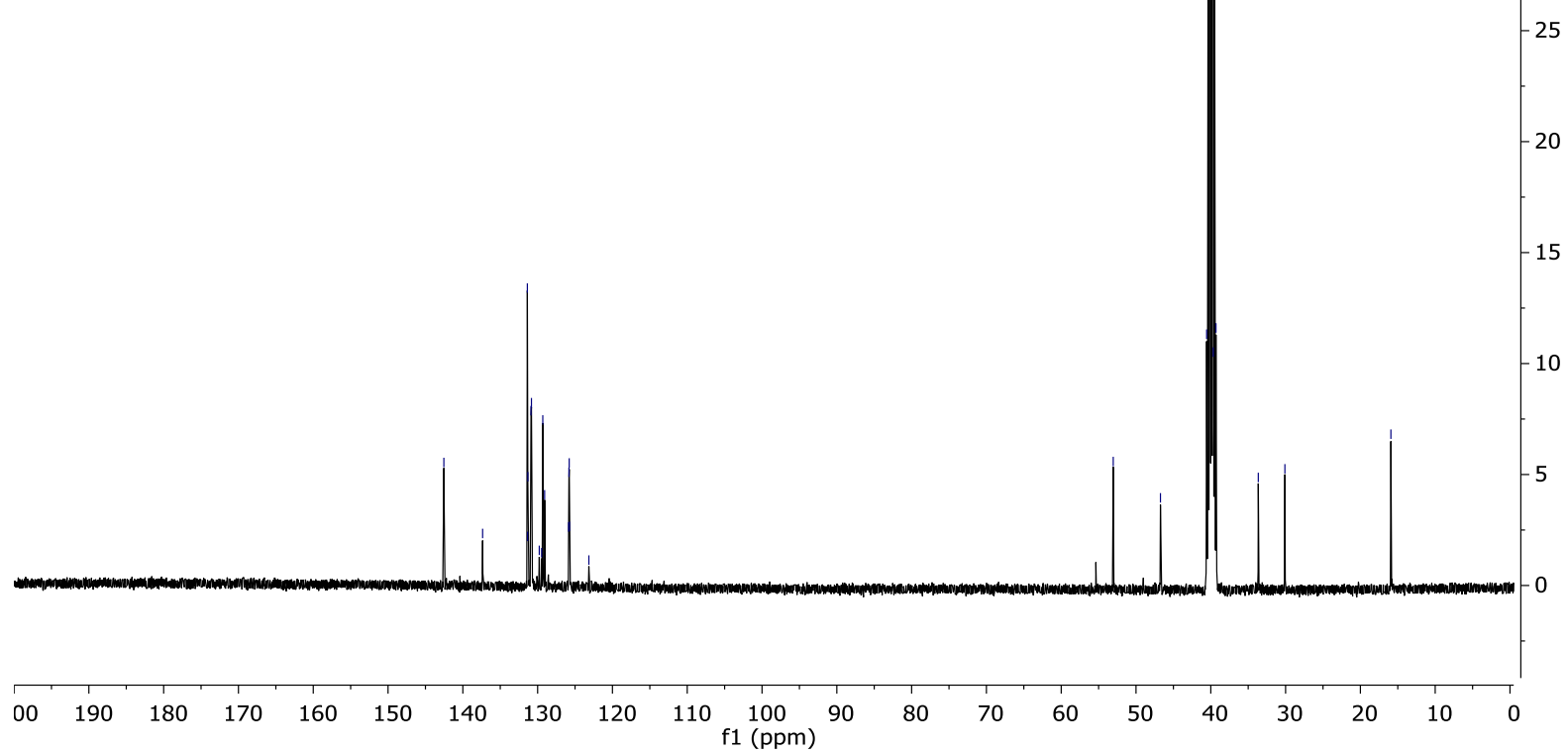




\section{Acme Bioscience, Inc. LC-MS Report}

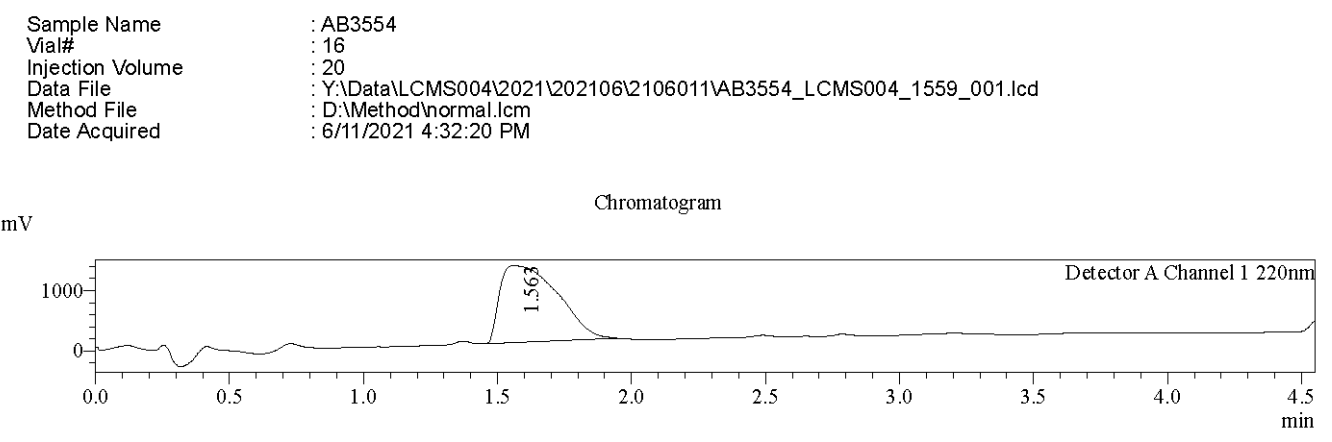

$\mathrm{mV}$

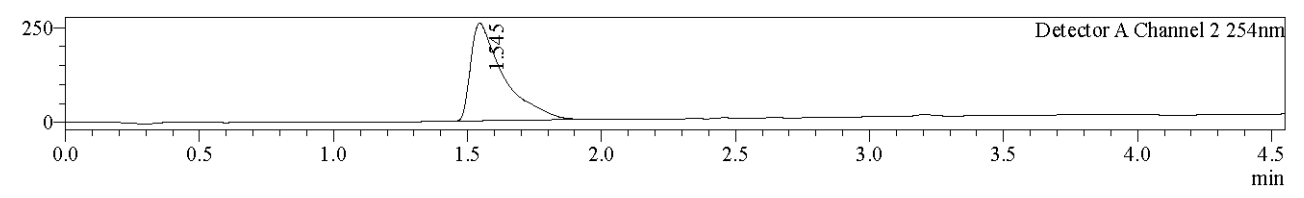

1 Det.ACh $1 / 220 \mathrm{~nm}$

2 Det.A Ch $2 / 254 \mathrm{~nm}$

Detector A Channel $1220 \mathrm{~nm}$
\begin{tabular}{|r|r|r|c|c|c|c|c|}
\hline Peak\# & Ret. Time & Area & Height & Conc. & Unit & Mark & \\
\hline 1 & 1.563 & 18904199 & 1277315 & 100.000 & & M & \\
\hline Total & & 18904199 & 1277315 & & & & \\
\hline
\end{tabular}

Detector A Channel $2254 \mathrm{~nm}$
\begin{tabular}{|r|r|r|r|r|r|r|r|}
\hline Peak\# & Ret. Time & \multicolumn{1}{l|}{ Arca } & \multicolumn{1}{l|}{ Height } & Conc. & Unit & Mark & Name \\
\hline 1 & 1.545 & 2182935 & 257205 & 100.000 & & M & \\
\hline Total & & 2182935 & 257205 & & & & \\
\hline
\end{tabular}

Line\#:1 R.Time:1.567(Scan\#:95)

MS Spectrum Graph

MassPeaks:943

Spectrum Mode:Single 1.567(95) BasePeak:376.20(3897246)

BG Mode:None Segment 1 - Event 1

ESI Positive

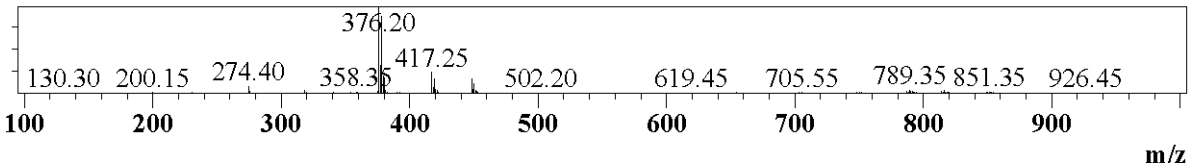

Line\#:2 R.Time:1.583(Scan\#:96)

MassPeaks: 1027

Spectrum Mode:Single 1.583(96) BasePeak:227.05(308136)

BG Mode:None Segment 1 - Event 2

ESI Negative

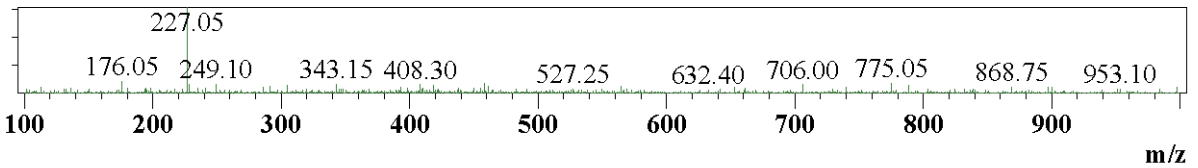




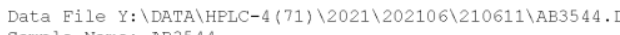
Sample Name: AB354
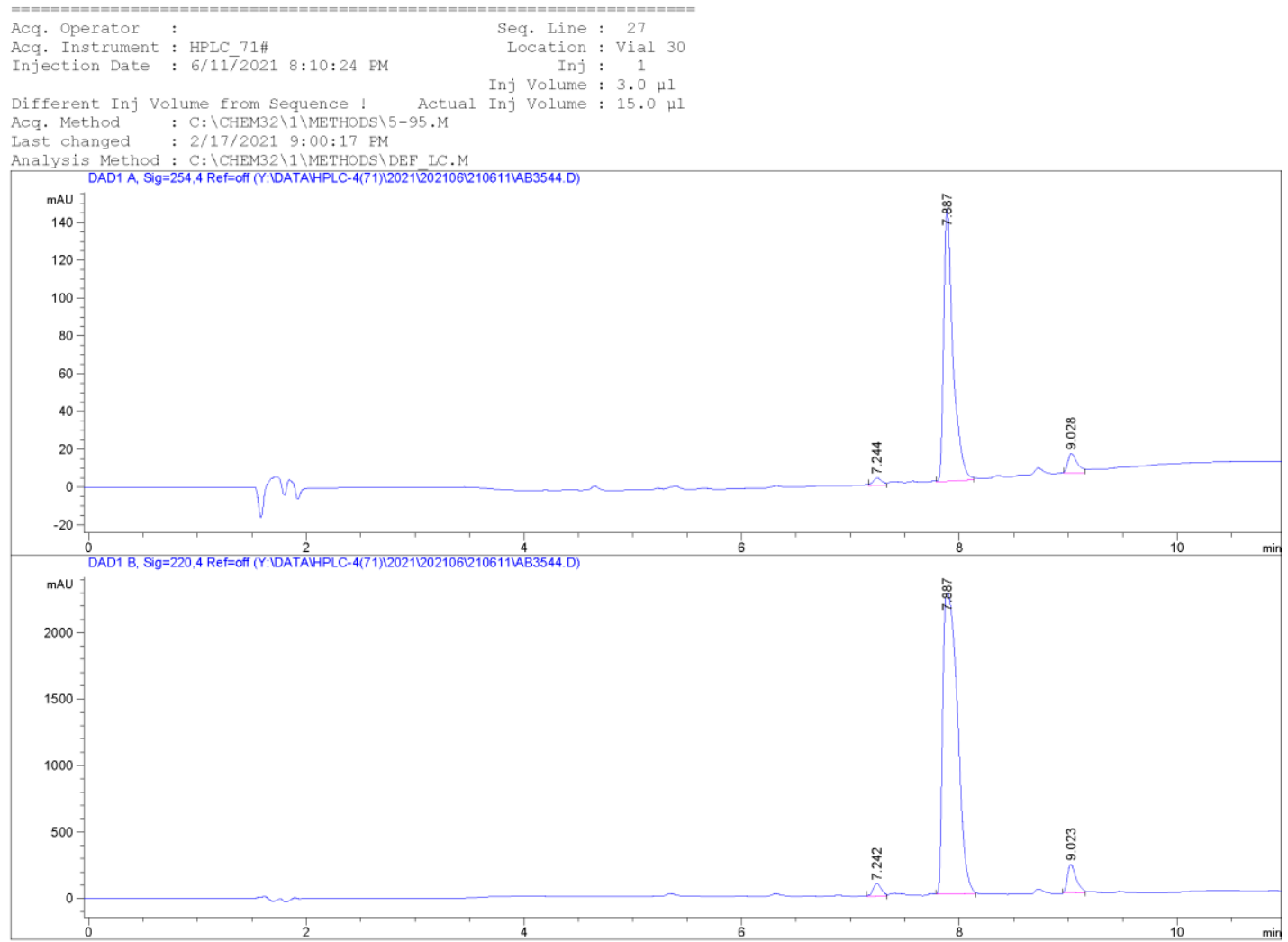

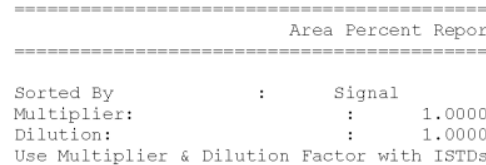

Use Multiplier \& Dilution Factor with ISTDs

Signal 1: DAD1 A, Sig $=254,4$ Ref $=0$ ff

\begin{tabular}{|c|c|c|c|c|c|c|}
\hline $\begin{array}{c}\text { Peak } \\
\#\end{array}$ & 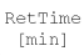 & Type & $\begin{array}{l}\text { Width } \\
\text { [min] }\end{array}$ & $\begin{array}{c}\text { Area } \\
{\left[\mathrm{mAU}^{*} \mathrm{~s}\right]}\end{array}$ & $\begin{array}{l}\text { Height } \\
\text { [mAU] }\end{array}$ & $\begin{array}{c}\text { Area } \\
8\end{array}$ \\
\hline 1 & 7.244 & MM R & 0.0946 & 22.41381 & 3.94924 & 2.3858 \\
\hline 2 & 7.887 & $M M R$ & 0.0982 & 853.03534 & 144.77351 & 90.7980 \\
\hline 3 & 9.028 & MM R & 0.1019 & 64.03758 & 10.47033 & 6.8162 \\
\hline
\end{tabular}

$\begin{array}{lll}\text { Totals : } \quad 939.48673 & 159.19308\end{array}$

Signal 2: DAD1 B, Sig=220, 4 Ref $=0 f f$

\begin{tabular}{|c|c|c|c|c|c|c|}
\hline $\begin{array}{l}\text { eak } \\
\text { \# }\end{array}$ & $\begin{array}{l}\text { RetTime } \\
{[\text { min] }}\end{array}$ & Type & $\begin{array}{l}\text { Width } \\
\text { [min] }\end{array}$ & $\begin{array}{c}\text { Area } \\
{\left[\mathrm{mAU}^{*} \mathrm{~s}\right]}\end{array}$ & $\begin{array}{l}\text { Height } \\
\text { [mAU] }\end{array}$ & $\begin{array}{c}\text { Area } \\
\frac{8}{8}\end{array}$ \\
\hline & & & & & & \\
\hline & & & & & & \\
\hline & 9.023 & & .0900 & 1151.60510 & 213.14304 & 5.0680 \\
\hline
\end{tabular}

Totals : $\quad 2.27232 \mathrm{e} 4 \quad 2577.05959$

t** End of Report $\star \star \star *$ 


\section{Compound S-2}

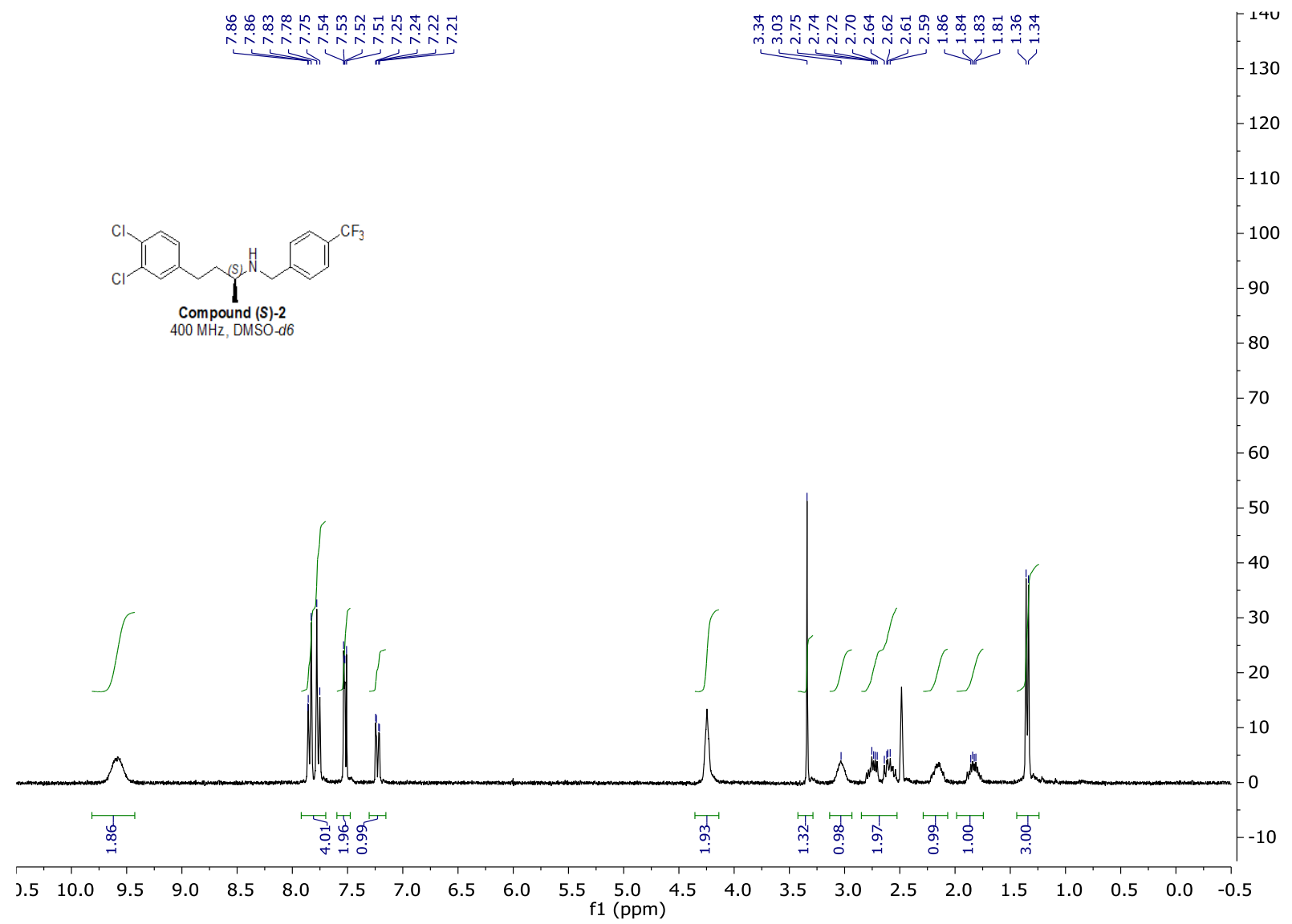




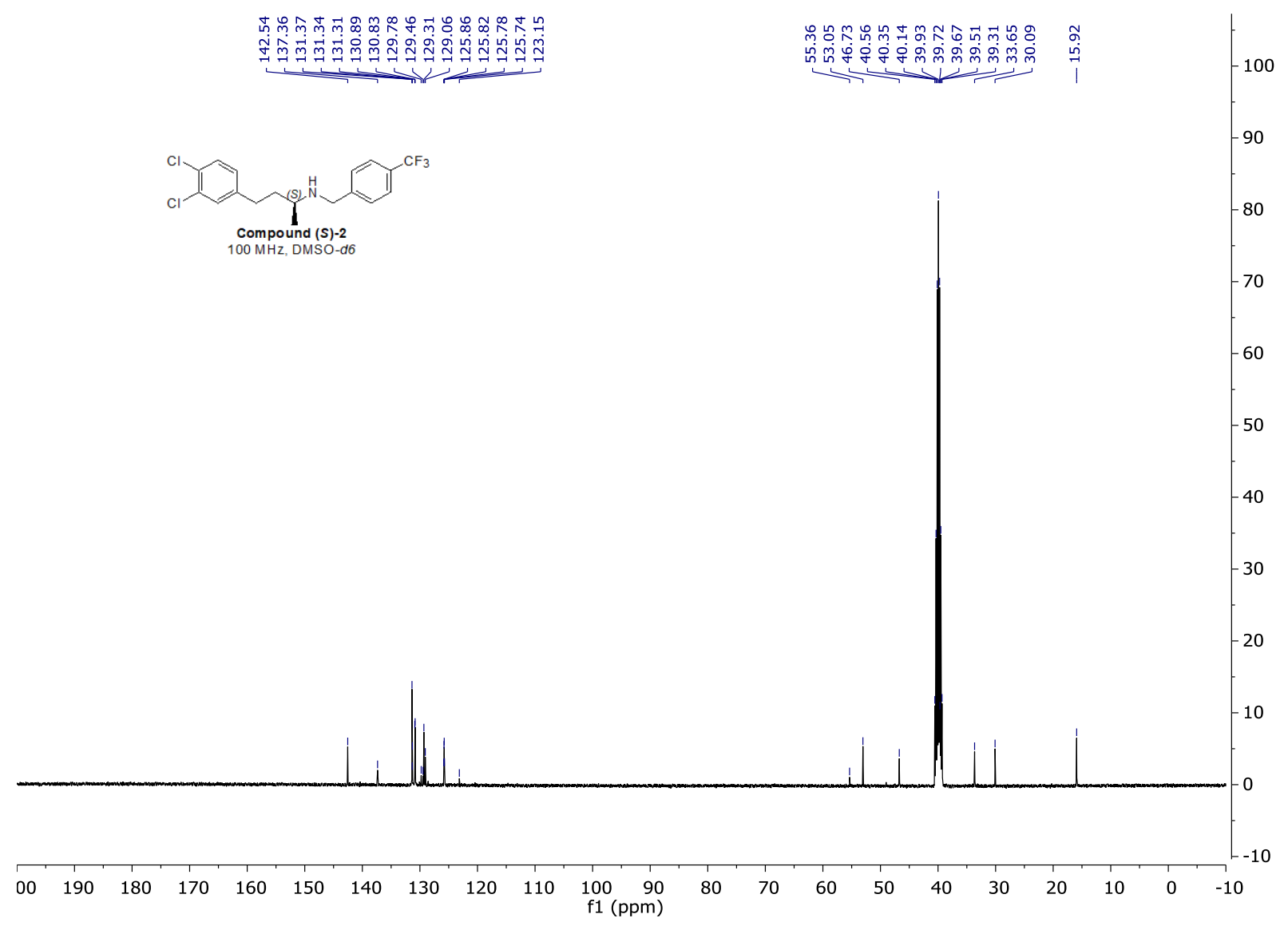




\section{Acme Bioscience, Inc.}

\section{LC-MS Report}
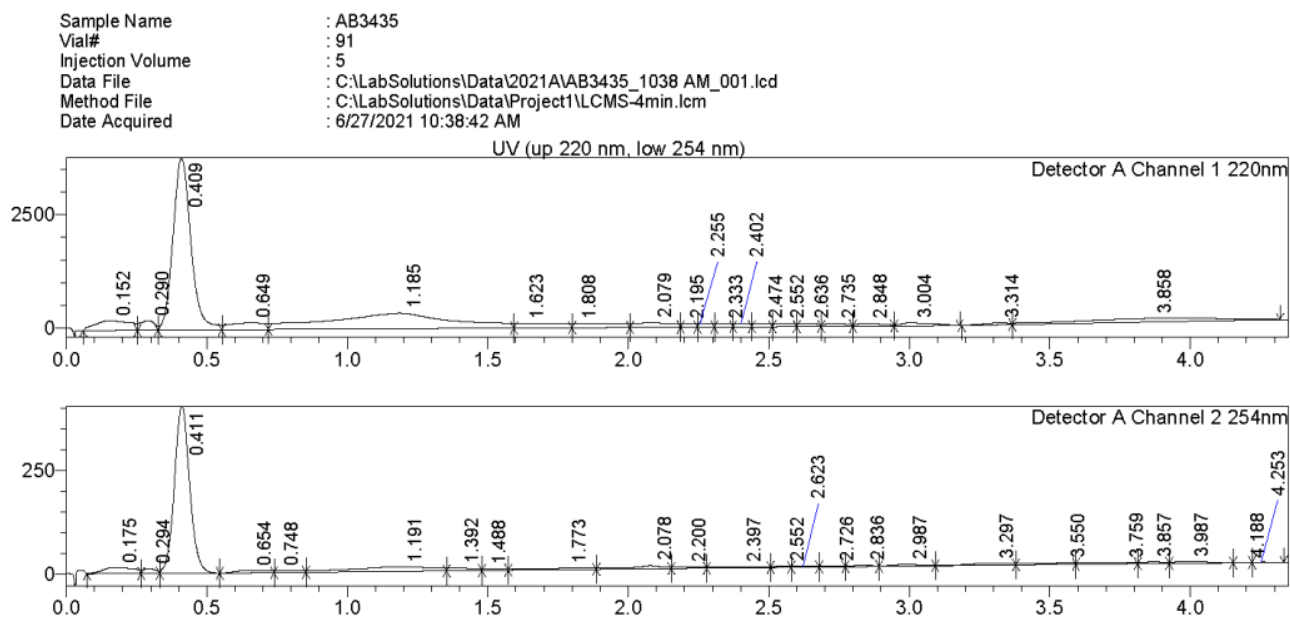

1 Det.A Ch1 / $220 \mathrm{~nm}$

2 Det.A Ch2 / $254 \mathrm{~nm}$

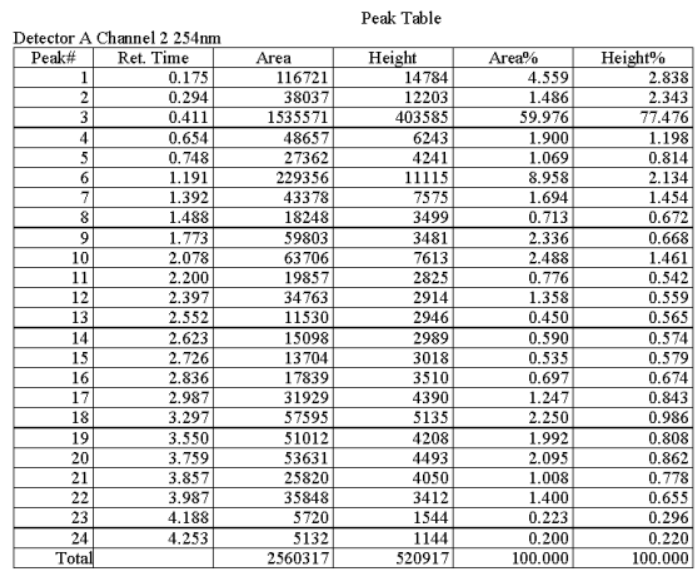

Line\#:1 R.Time:0.440(Scan\#:133)

MS Spectrum Graph

MassPeaks:955

Spectrum Mode:Single 0.440(133) BasePeak:377.50(15626053)

BG Mode:None Segment 1 - Event 1

ESI Positive

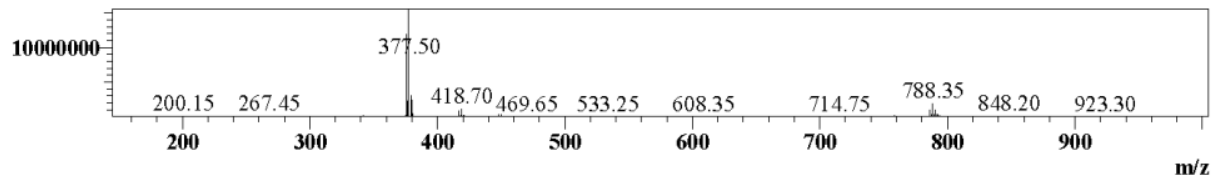




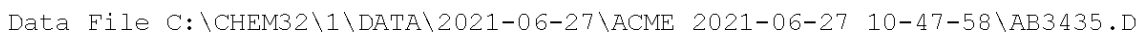

Sample Name: AB3435
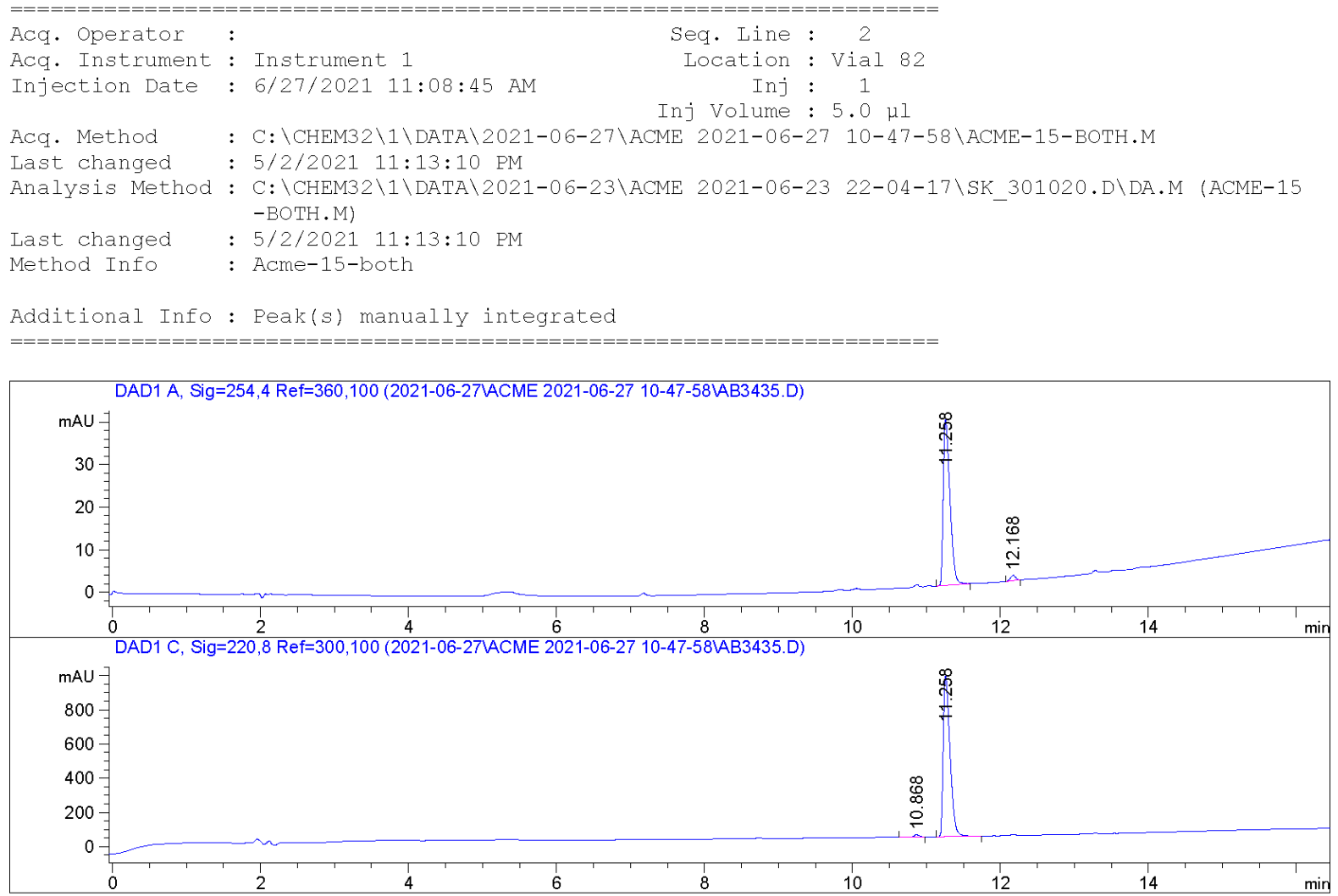

Area Percent Report

\begin{tabular}{|c|c|c|c|c|}
\hline Sorted By & : & Signal & & \\
\hline Multiplier & : & 1.0000 & & \\
\hline Dilution & : & 1.0000 & & \\
\hline Use Multiplier \& I & ilution & Factor with & ISTDS & \\
\hline \multicolumn{5}{|c|}{ Signal 1: DAD1 A, Sig=254,4 Ref=360,100 } \\
\hline $\begin{array}{c}\text { Peak RetTime Type } \\
\# \quad[\min ]\end{array}$ & $\begin{array}{l}\text { Width } \\
{[\text { min }]}\end{array}$ & $\begin{array}{c}\text { Area } \\
{\left[\mathrm{mAU}^{*} \mathrm{~s}\right]}\end{array}$ & $\begin{array}{l}\text { Height } \\
\text { [mAU] }\end{array}$ & $\begin{array}{c}\text { Area } \\
\frac{\circ}{8}\end{array}$ \\
\hline \multicolumn{5}{|c|}{$----|-------|----|-------|----------|----------|--------\mid$} \\
\hline $111.258 \mathrm{BB}$ & 0.0948 & 243.10684 & 38.94489 & 97.6674 \\
\hline $2 \quad 12.168 \mathrm{BB}$ & 0.0722 & 5.80618 & 1.24920 & 2.3326 \\
\hline Totals : & & 248.91303 & 40.19409 & \\
\hline
\end{tabular}




\section{Compound 3}

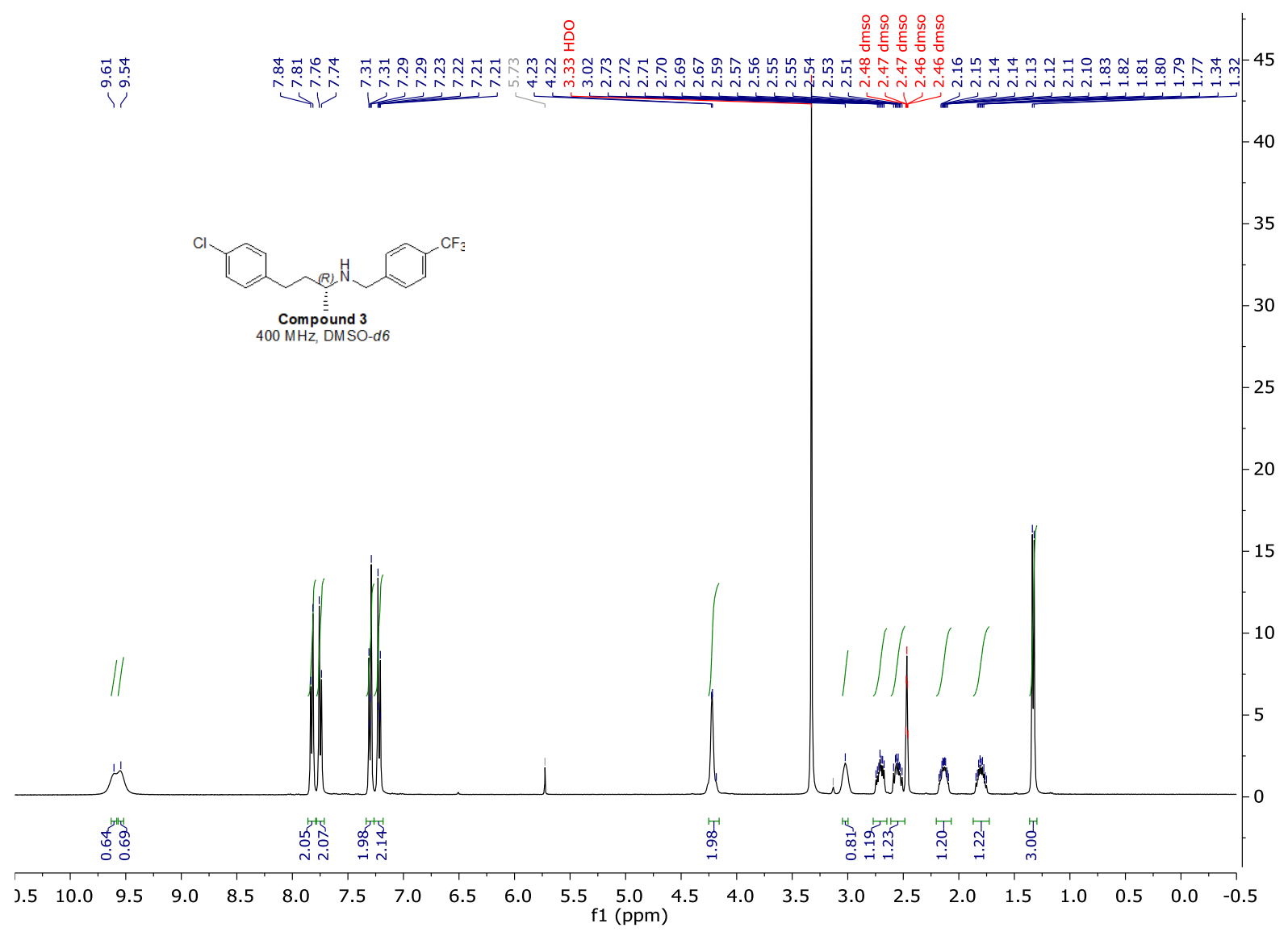




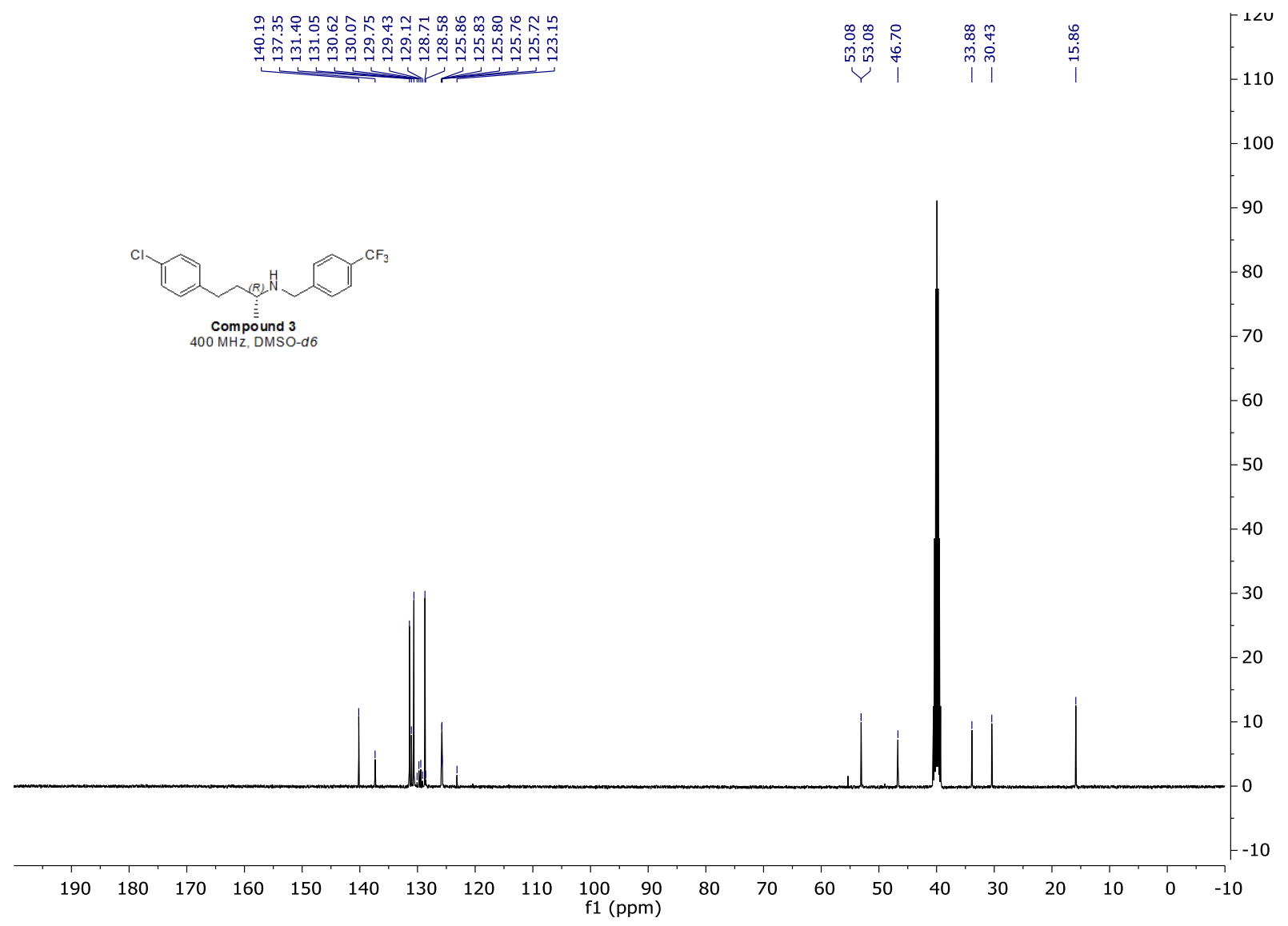




\section{Acme Bioscience, Inc. LC-MS Report}

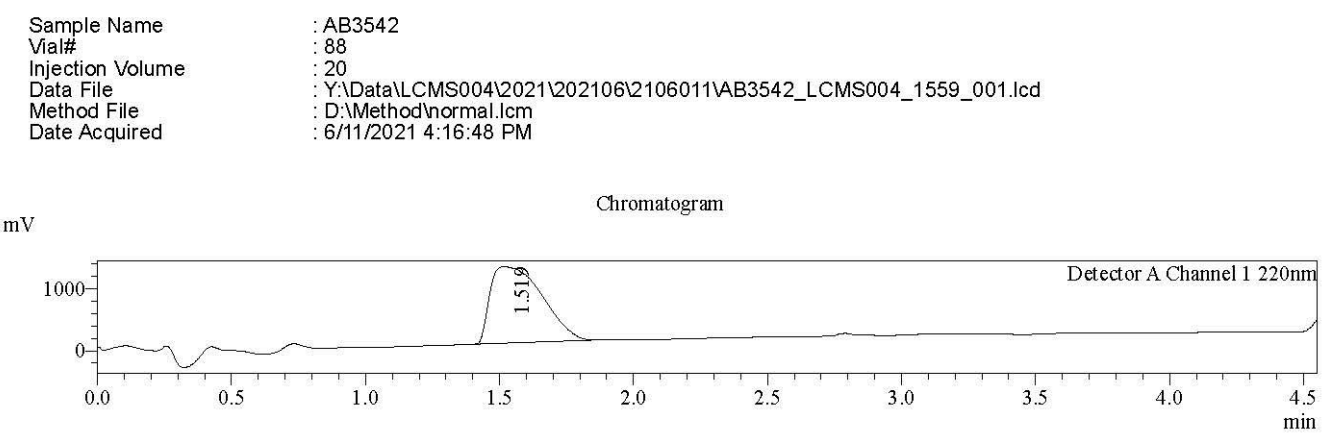

$\mathrm{mV}$

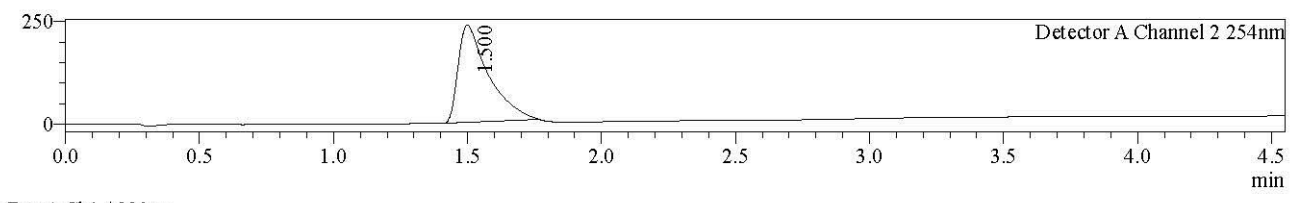

1 Det.ACh $1 / 220 \mathrm{~nm}$

2 Det.ACh $2 / 254 \mathrm{~nm}$

\begin{tabular}{|c|c|c|c|c|c|c|c|}
\hline \multicolumn{8}{|c|}{ Peak Table } \\
\hline Peak\# & Ret. Time & Area & Height & Conc. & Unit & Mark & Name \\
\hline 1 & 1.519 & $\begin{array}{l}16375551 \\
16375551\end{array}$ & $\begin{array}{r}1228665 \\
1228665\end{array}$ & 100.000 & & M & \\
\hline
\end{tabular}

Detector A Channel $2254 \mathrm{~nm}$
\begin{tabular}{|r|r|r|r|r|r|r|r|}
\hline Peak\# & Ret. Time & Arca & Height & Conc. & Unit & Mark & Name \\
\hline 1 & 1.500 & 1831863 & 235033 & 100.000 & & M & \\
\hline Total & & 1831863 & 235033 & & & & \\
\hline
\end{tabular}

Line\#:1 R.Time:1.533(Scan\#:93)

MS Spectrum Graph

MassPeaks:987

Spectrum Mode:Single 1.533(93) BasePeak:342.25(3733544)

BG Mode: None Segment 1 - Event 1

ESI Positive

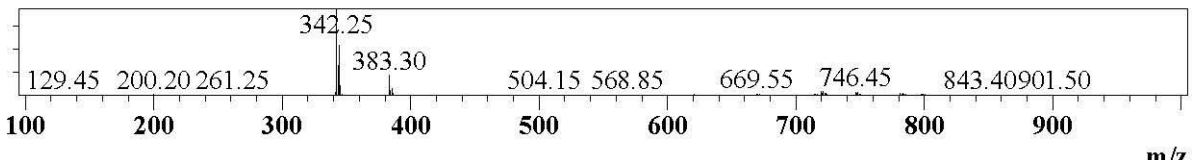

Line\#:2 R.Time:1.550(Scan\#:94)

MassPeaks: 1043

Spectrum Mode:Single 1.550(94) BasePeak:227.05(511051)

BG Mode:None Segment 1 - Event 2

ESI Negative

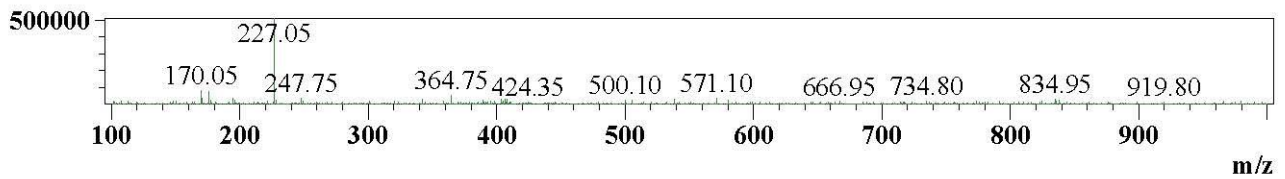




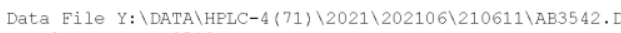
Sample Name: $A B 3542$
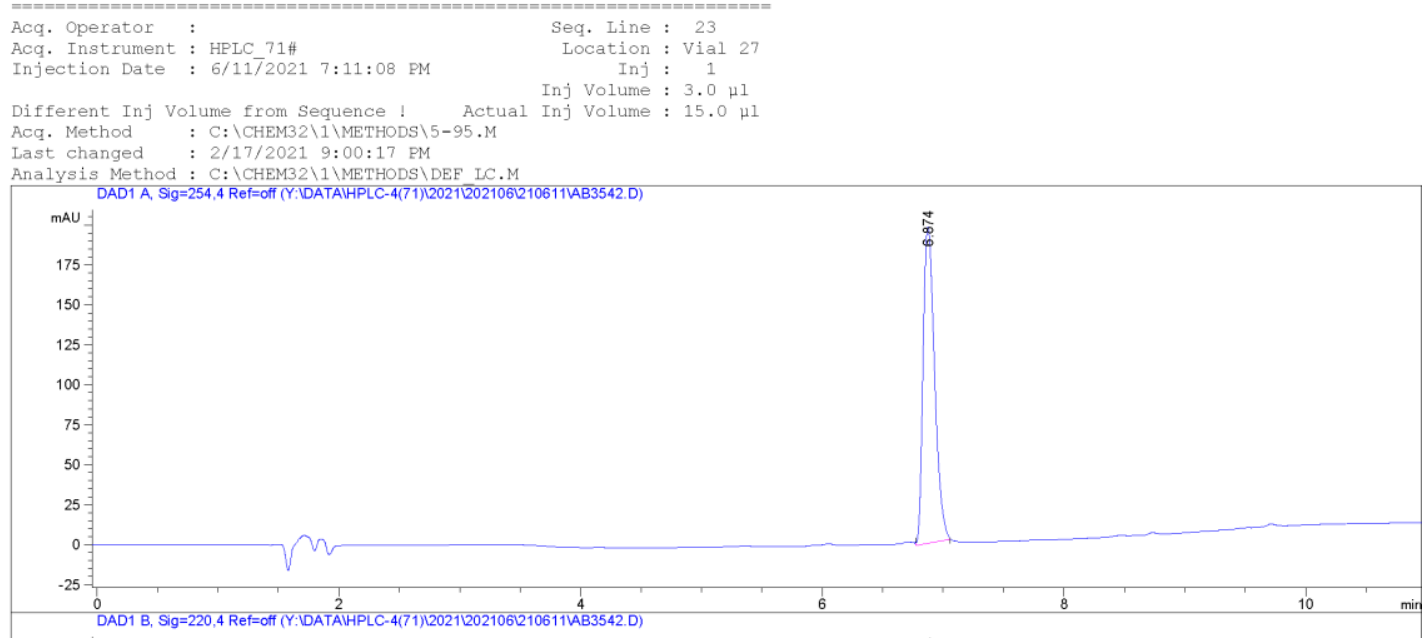
mAU - 


\section{Compound 4}

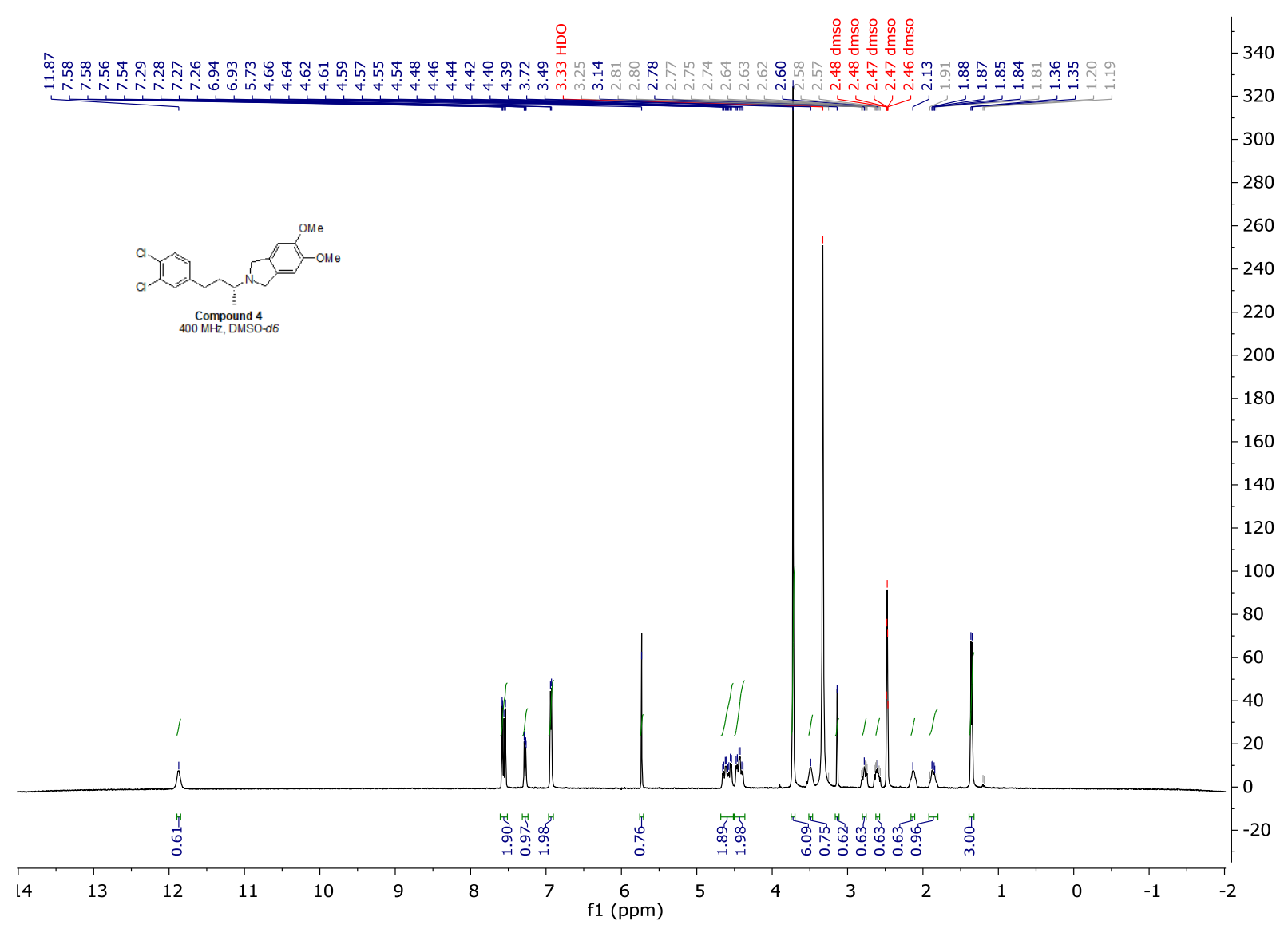




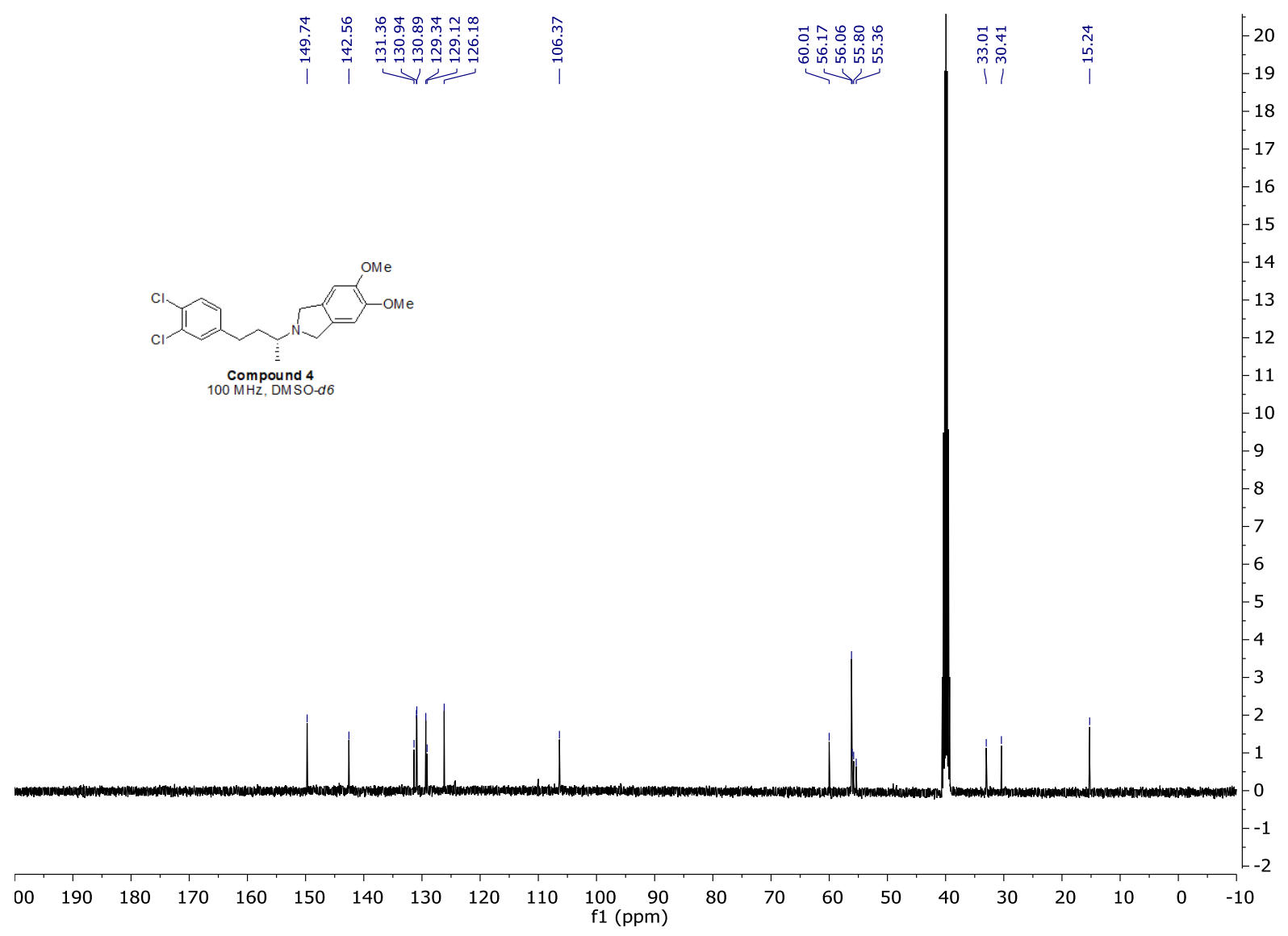




\section{Acme Bioscience, Inc. LC-MS Report}

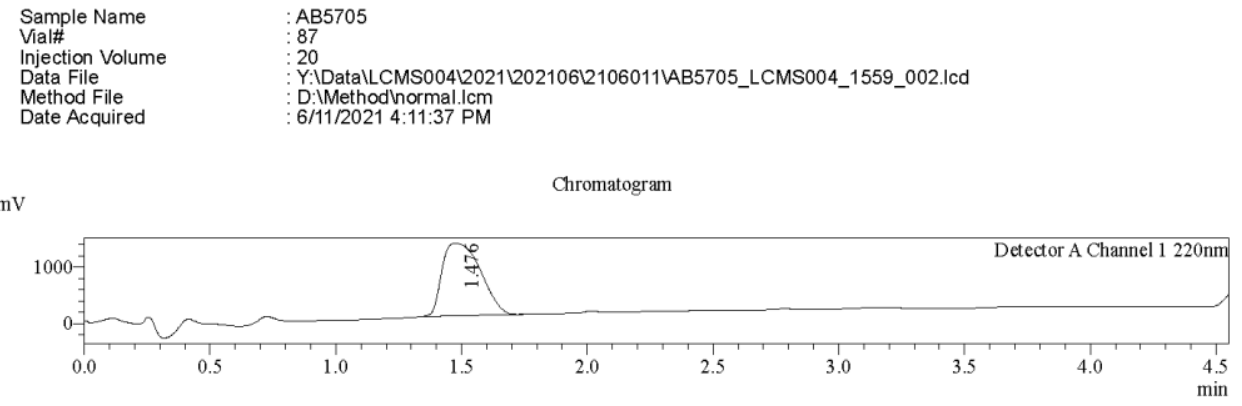

$\mathrm{mV}$

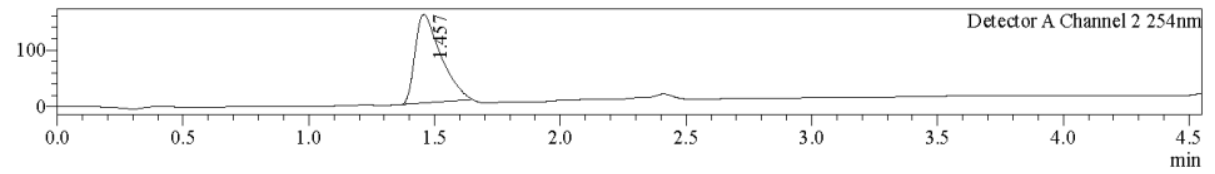

1 Det.A Ch1 $/ 220 \mathrm{~nm}$
2 Det.A Ch2 $/ 254 \mathrm{~nm}$
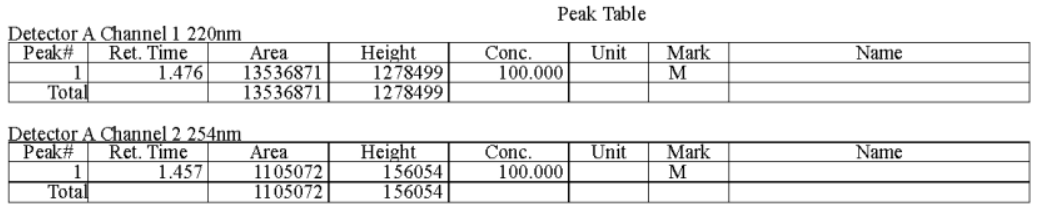

Line\#:1 R.Time:1.467(Scan\#:89)

MS Spectrum Graph

MassPeaks:964

Spectrum Mode:Single 1.467(89) BasePeak:380.25(4204368)

BG Mode: None Segment 1 - Event 1

ESI Positive

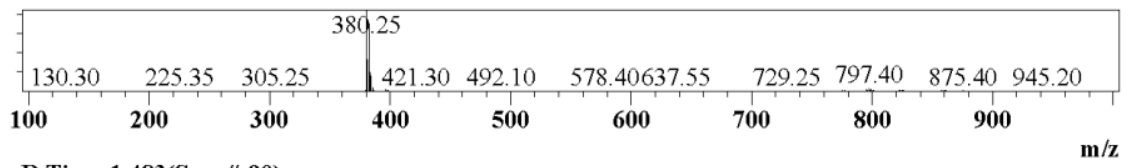

Line\#:2 R.Time:1.483(Scan\#:90)

MassPeaks:1003

Spectrum Mode:Single 1.483(90) BasePeak:249.05(540179)

BG Mode: None Segment 1 - Event 2

ESI Negative

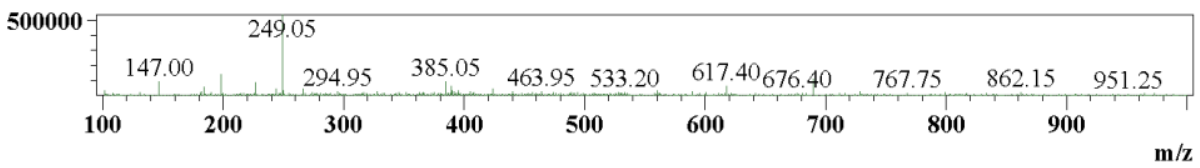




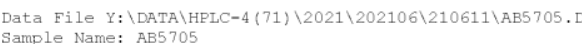

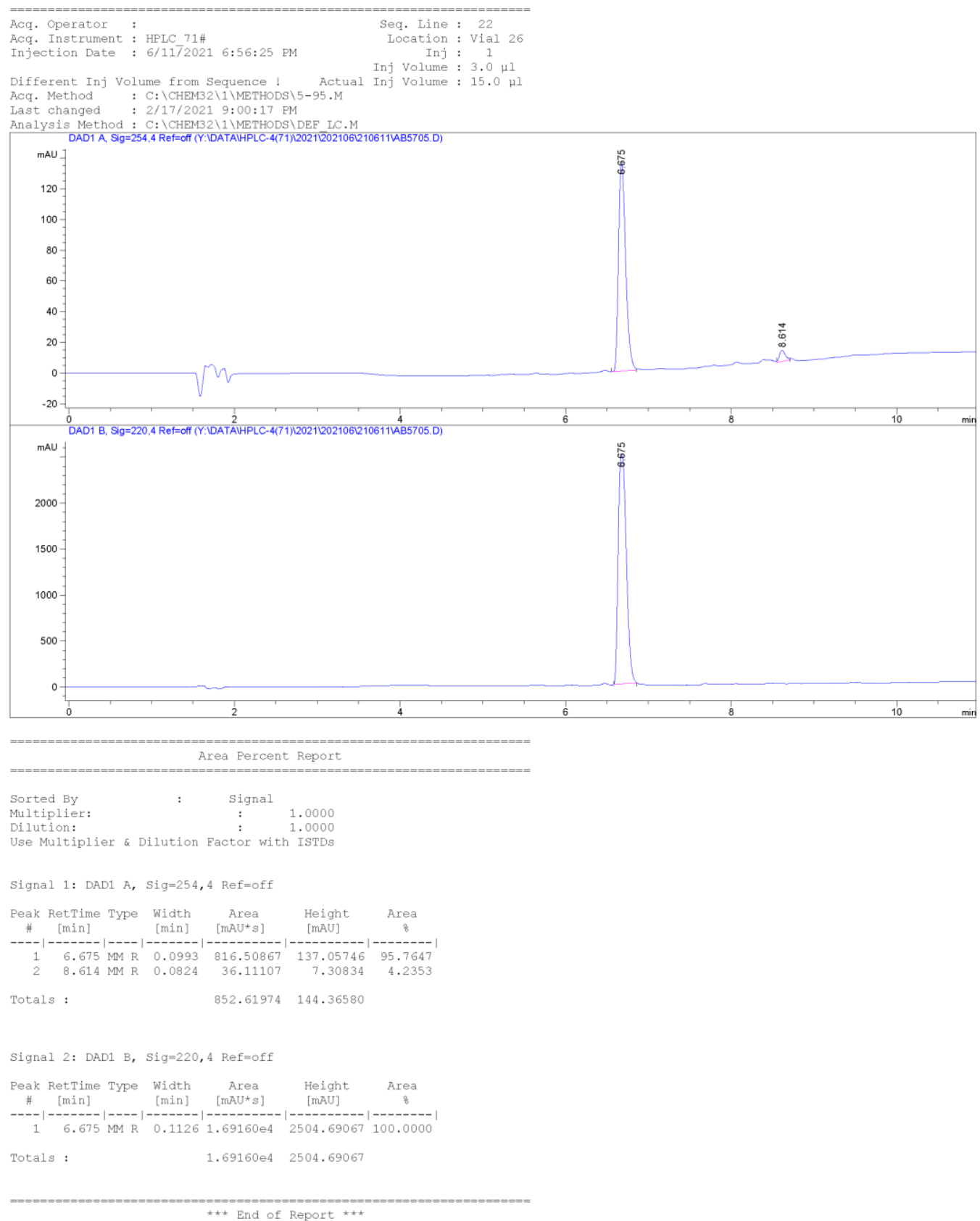

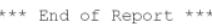




\section{Compound 5}

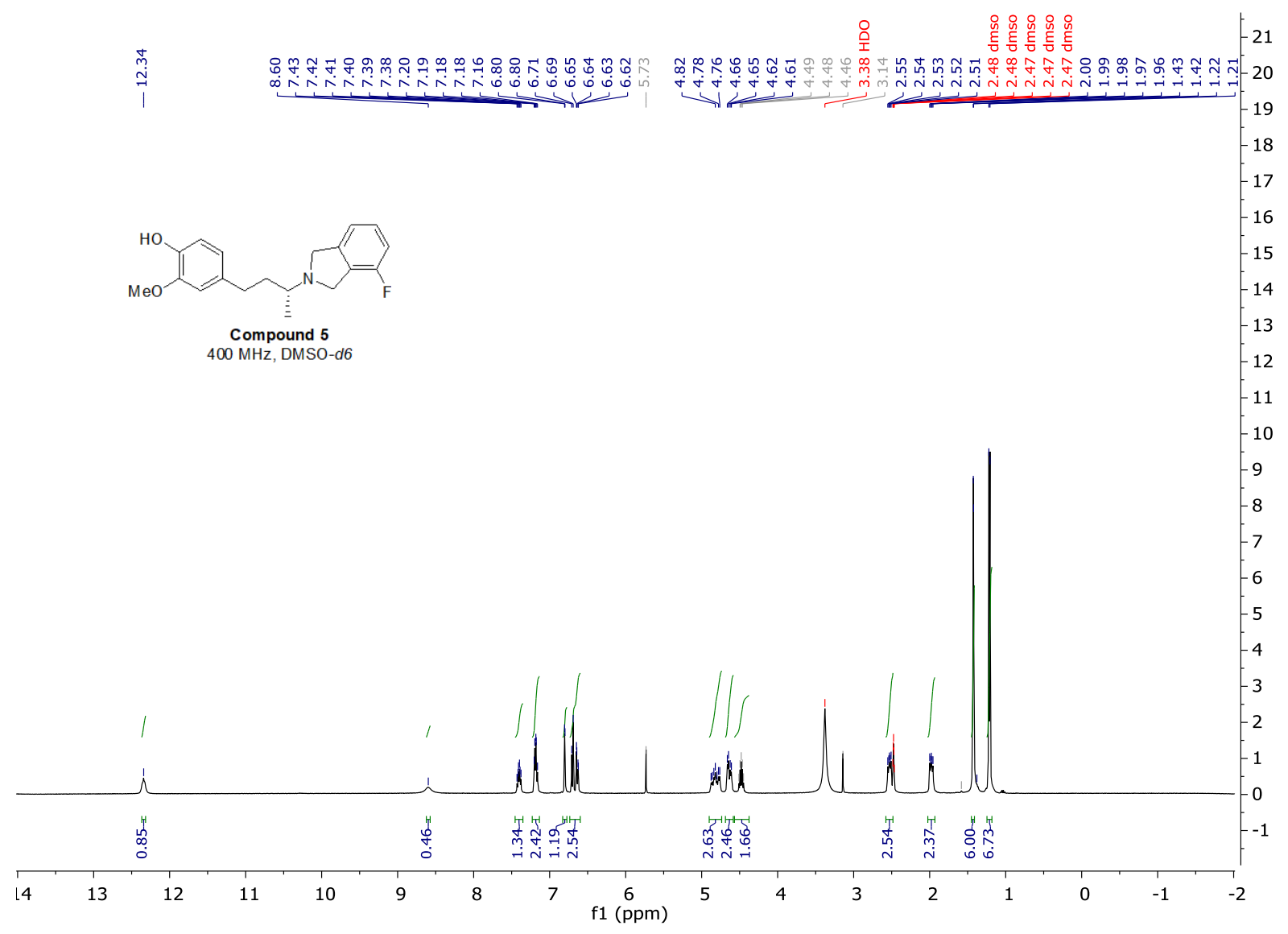




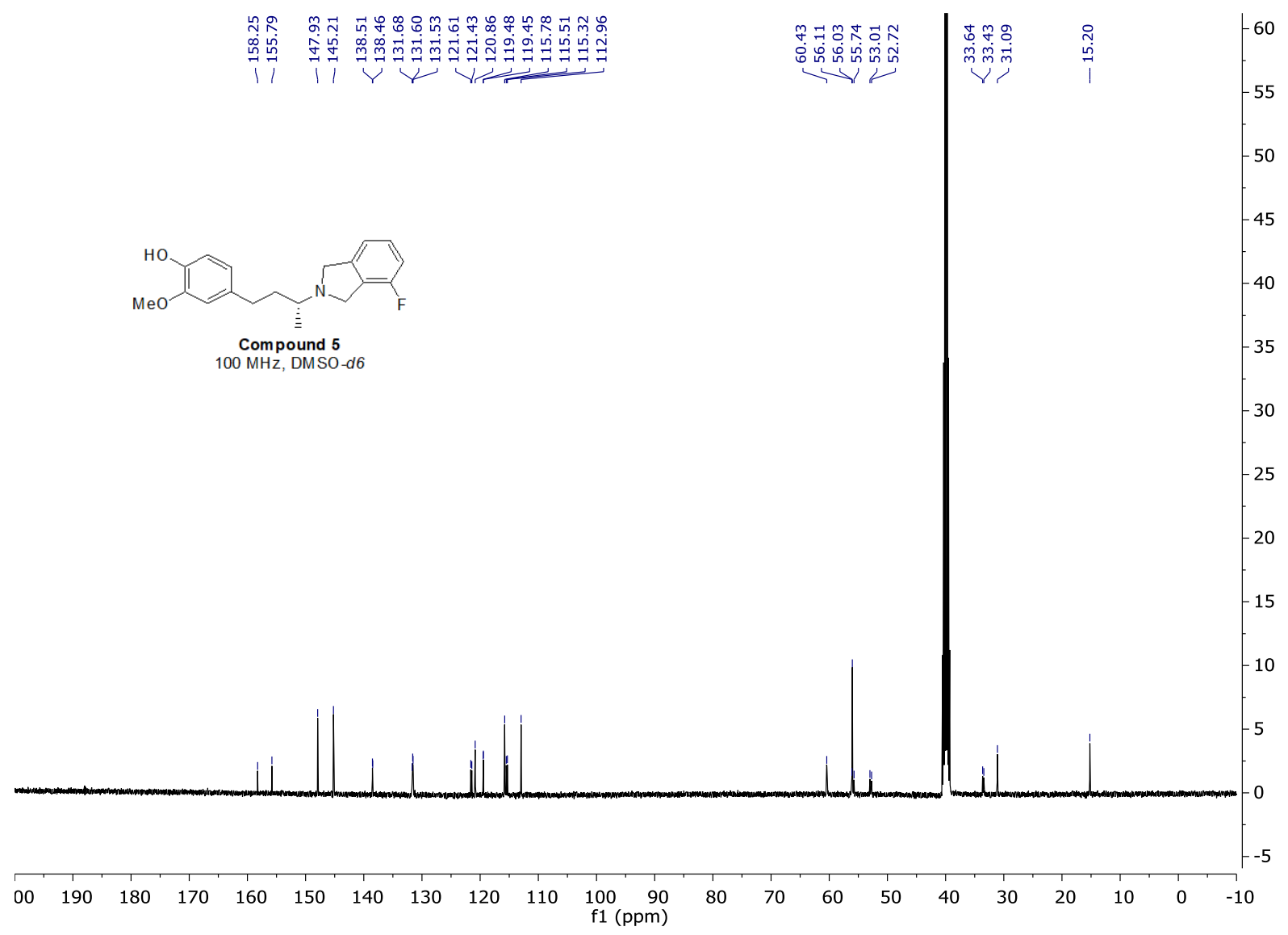




\section{Acme Bioscience, Inc. LC-MS Report}

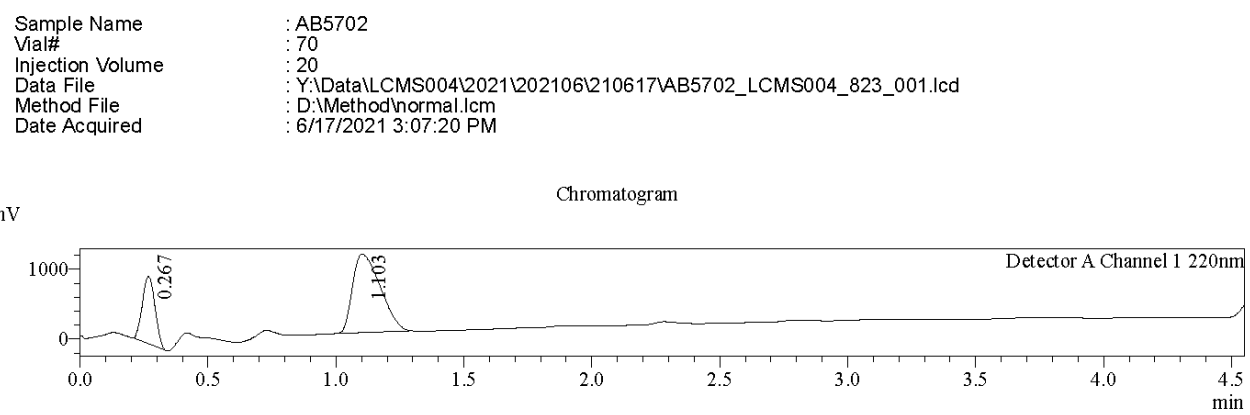

$\mathrm{mV}$

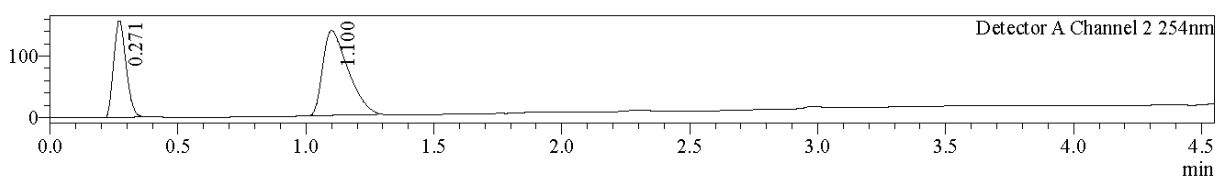

1 Det.ACh $1 / 220 \mathrm{~nm}$

2 Det.A Ch2 $/ 254 \mathrm{~nm}$

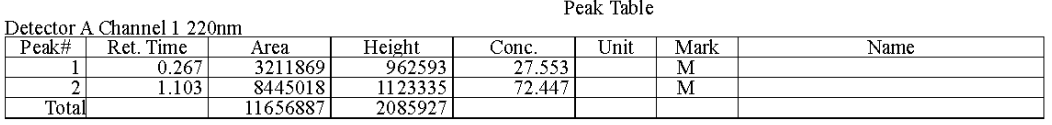

Detector A Channel $2254 \mathrm{~nm}$
\begin{tabular}{|r|r|r|r|r|r|r|r|}
\hline Peak\# & Ret. Time & \multicolumn{1}{|c|}{ Area } & Height & Conc. & Unit & Mark & Name \\
\hline 1 & 0.271 & 521137 & 156165 & 35.589 & & $\mathrm{M}$ & \\
\hline 2 & 1.100 & 943166 & 138337 & 64.411 & & $\mathrm{M}$ & \\
\hline Total & & 1464303 & 294501 & & & & \\
\end{tabular}

Line\#:1 R.Time:0.233(Scan\#:15)

MS Spectrum Graph

MassPeaks:961

Spectrum Mode:Single 0.233(15) BasePeak:316.30(2407060)

BG Mode: None Segment 1 - Event 1

ESI Positive

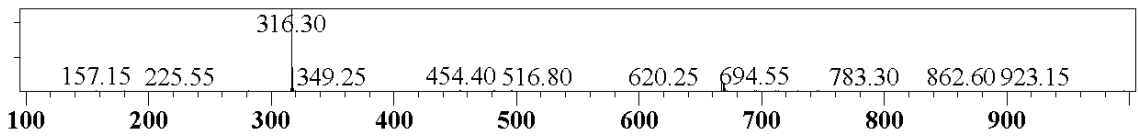

Line\#:2 R.Time:0.250(Scan\#:16)

MassPeaks:986

Spectrum Mode:Single 0.250(16) BasePeak:249.05(1064535)

BG Mode: None Segment 1 - Event 2

ESI Negative

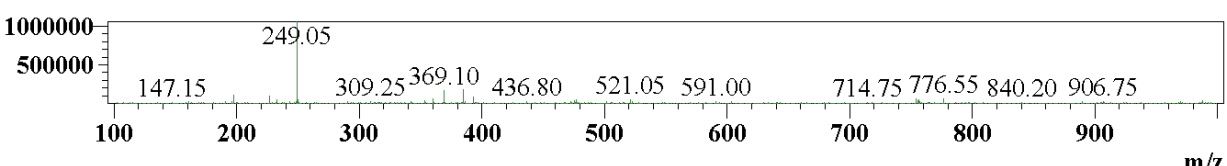




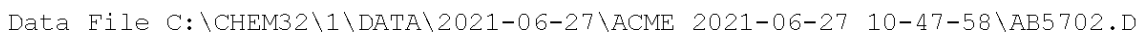

Sample Name: AB5702
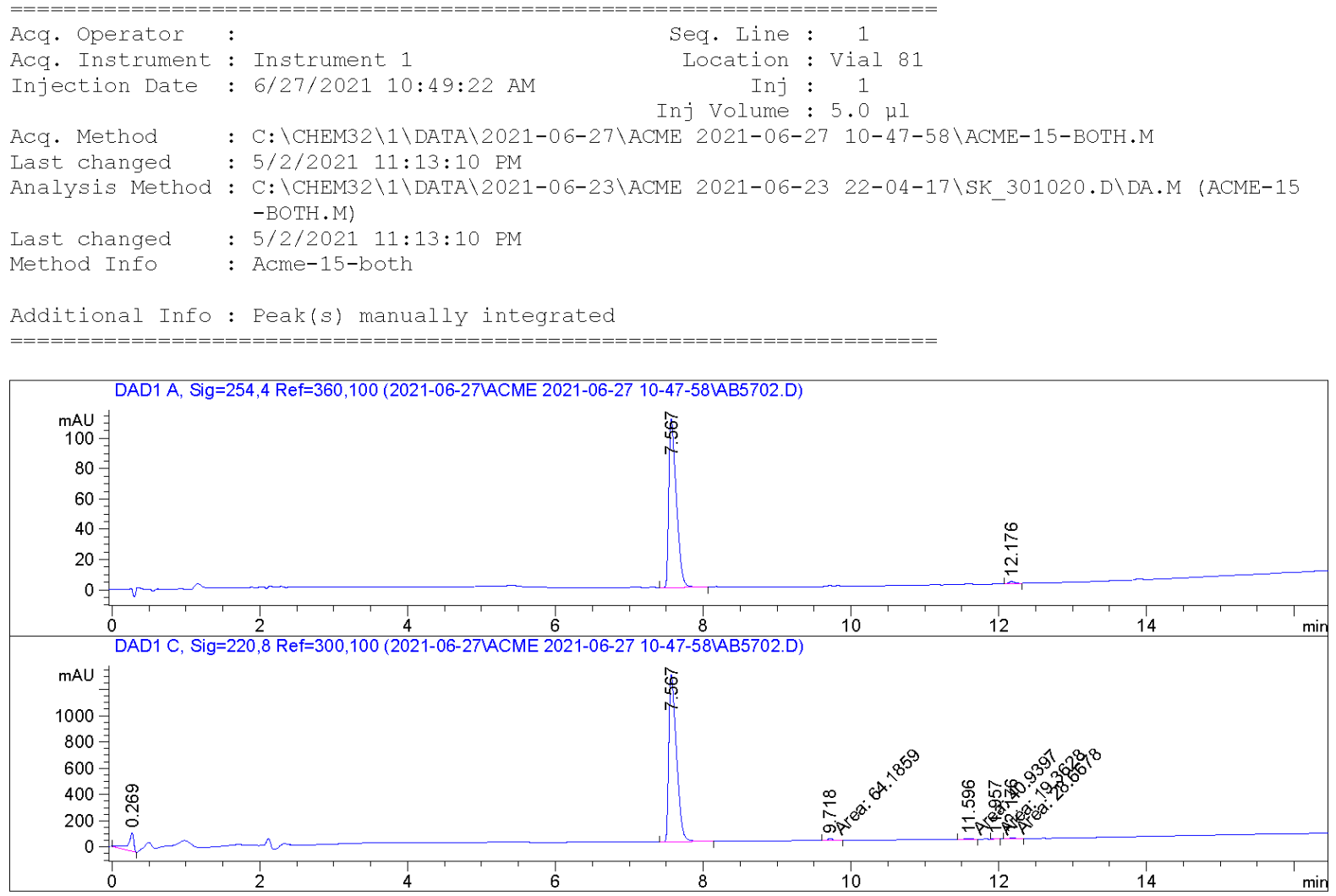

Area Percent Report

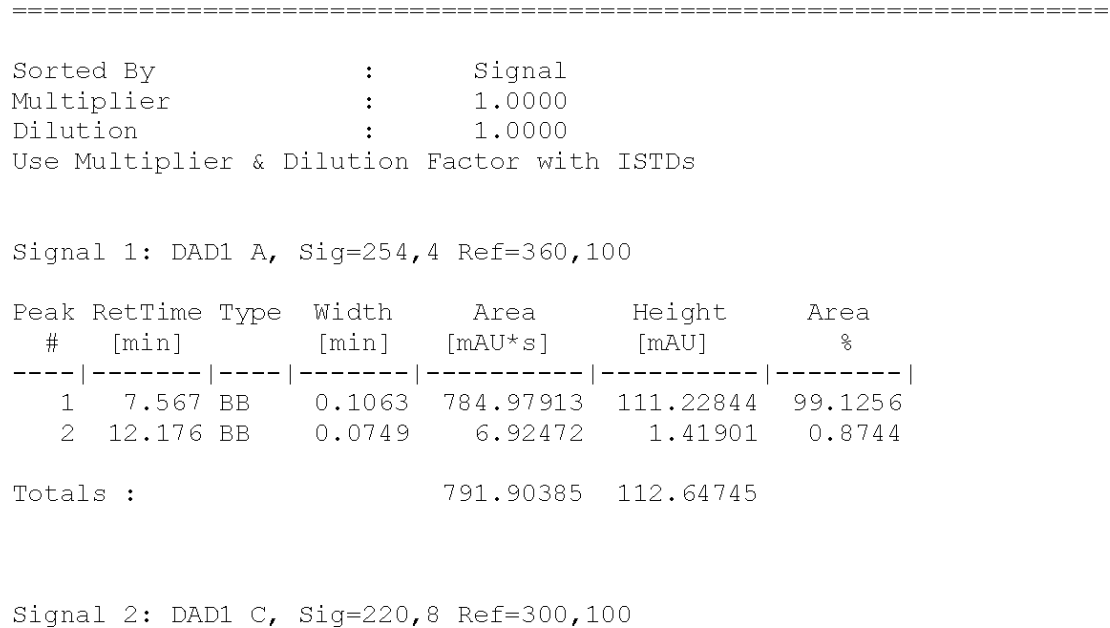




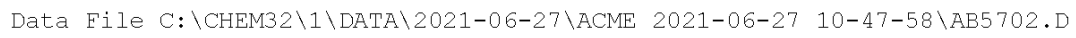
Sample Name: AB5702

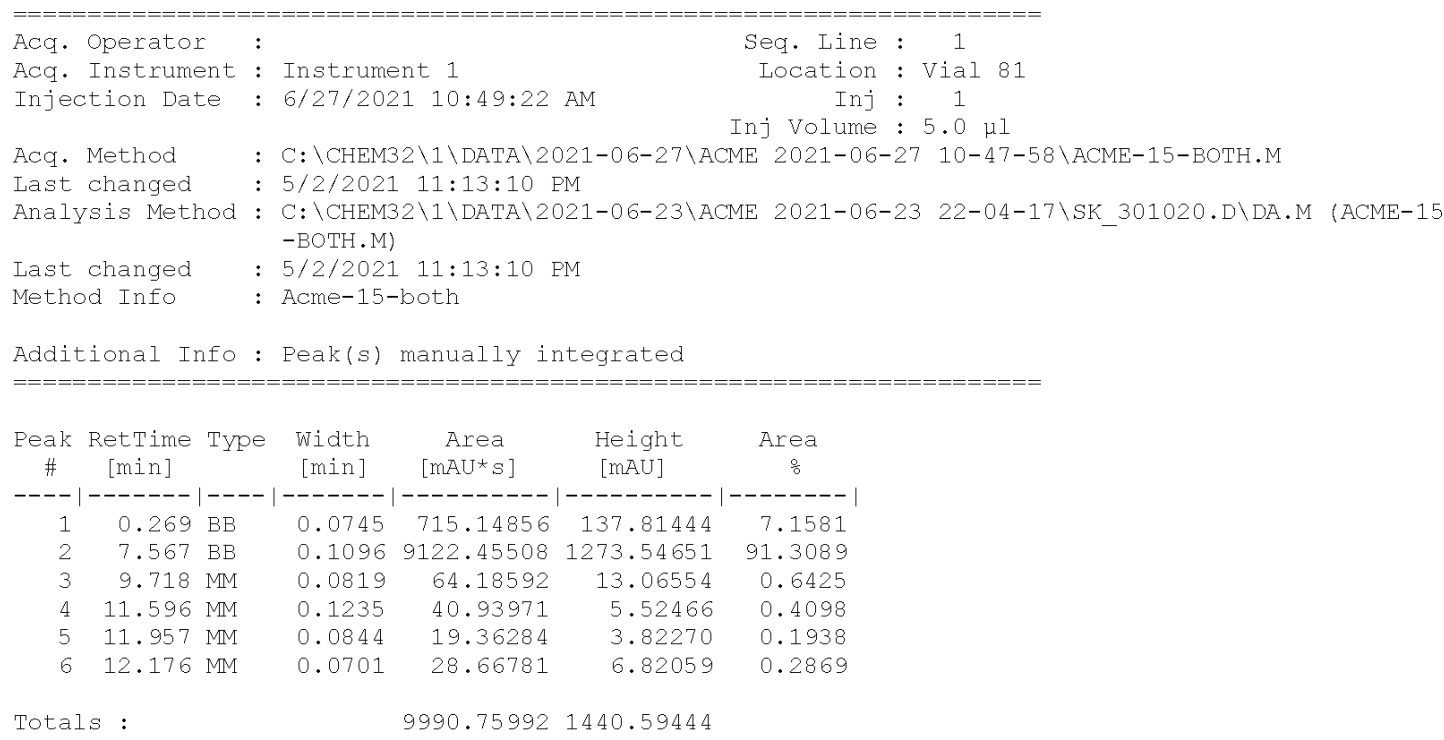

Totals :

$9990.75992 \quad 1440.59444$

*** End of Report *** 


\section{Compound 5}

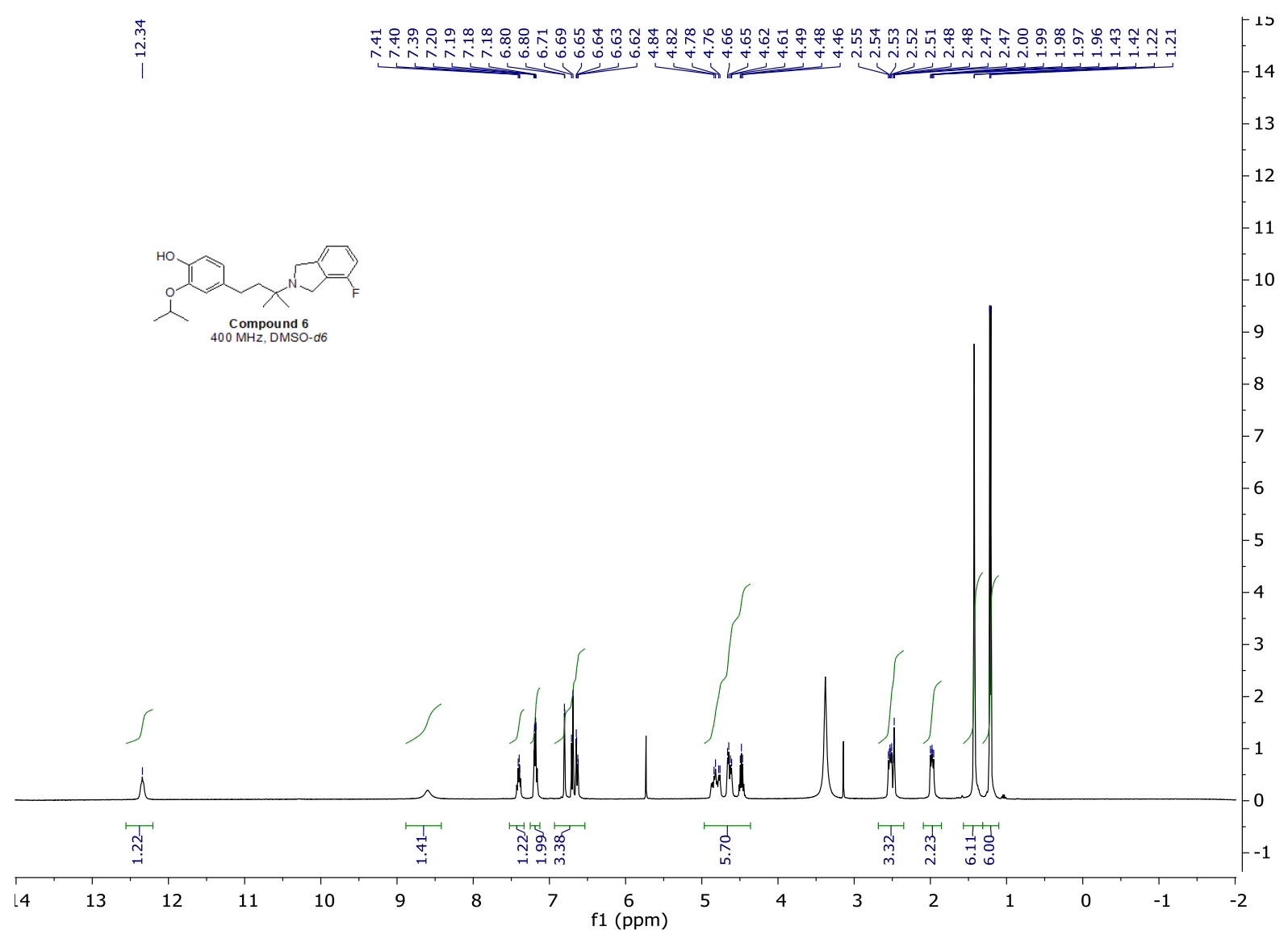




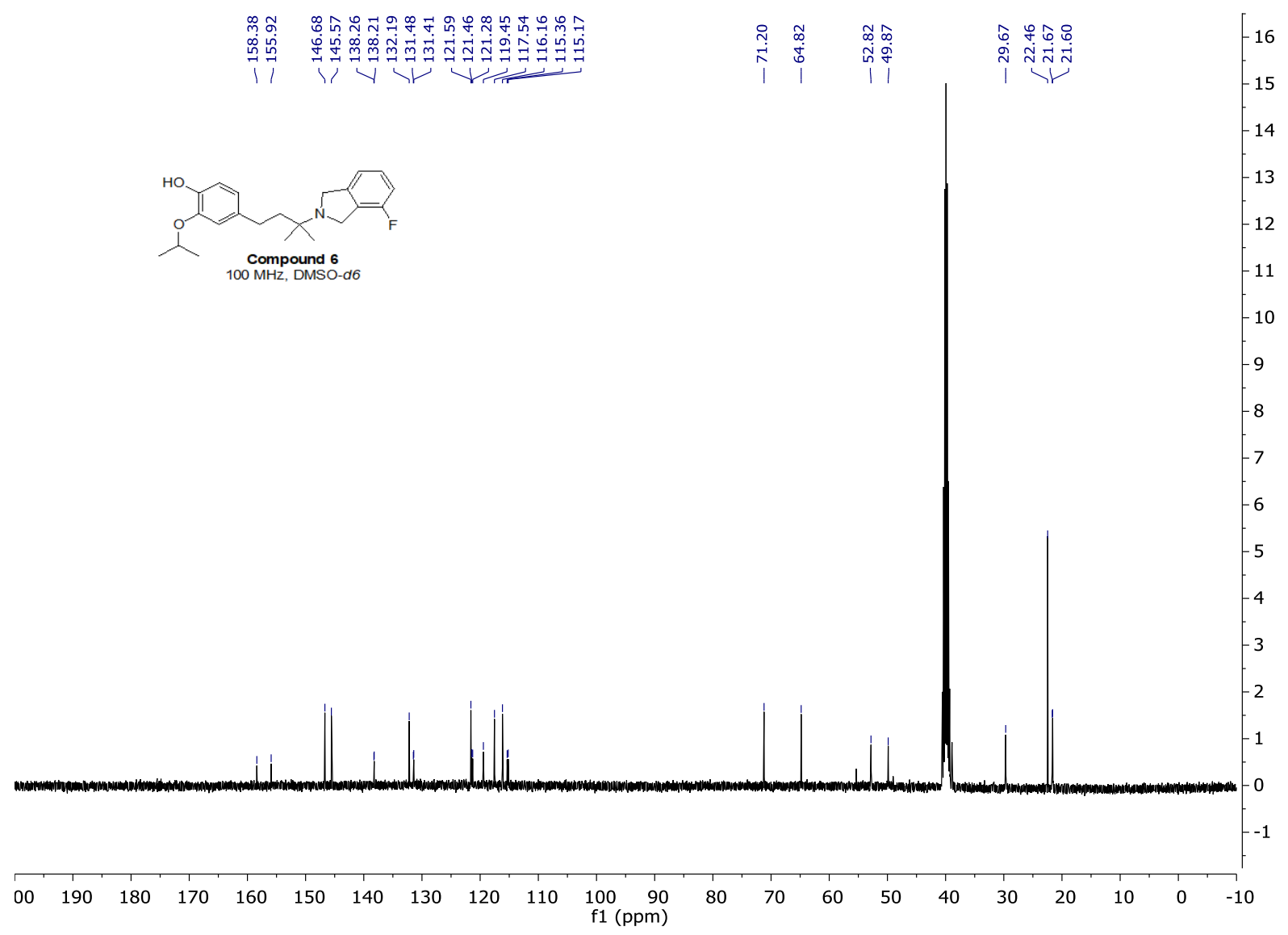




\section{Acme Bioscience, Inc. LC-MS Report}

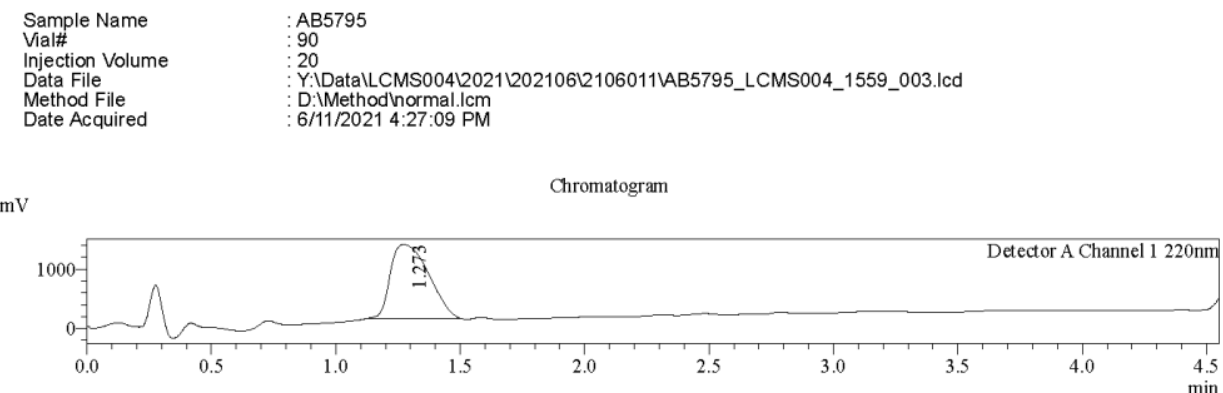

$\mathrm{mV}$

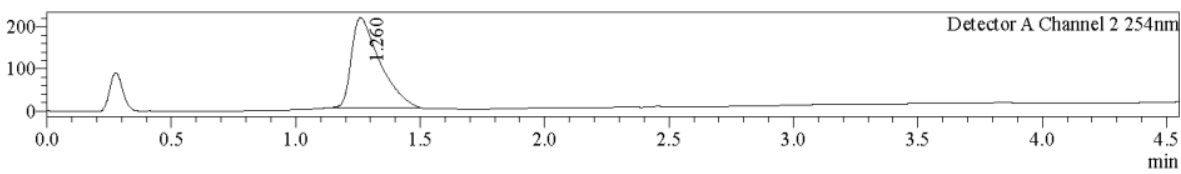

1 Det.A Chl $/ 220 \mathrm{~nm}$
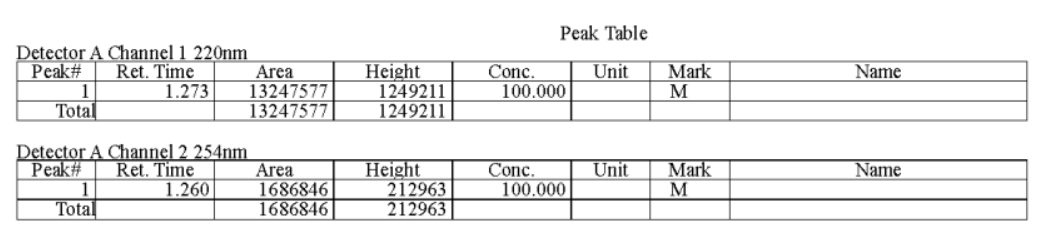

Line\#:1 R.Time:1.300(Scan\#:79)

MS Spectrum Graph

MassPeaks:970

Spectrum Mode:Single 1.300(79) BasePeak:358.35(4235118)

BG Mode:None Segment 1 - Event 1

ESI Positive

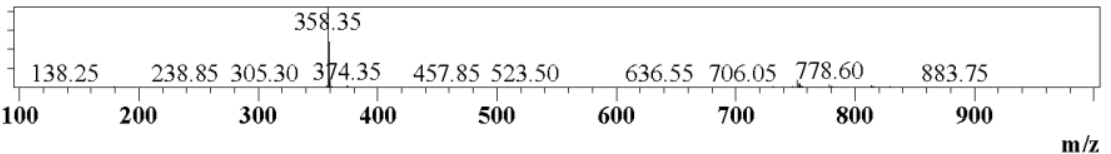

Line\#:2 R.Time:1.316(Scan\#:80)

MassPeaks:1015

Spectrum Mode:Single 1.316(80) BasePeak:227.05(124498)

BG Mode: None Segment 1 - Event 2

ESI Negative

$\mathbf{1 0 0 0 0 0}$
吾




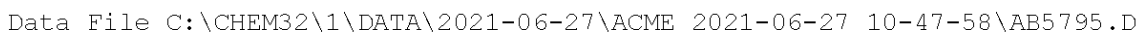

Sample Name: AB5795
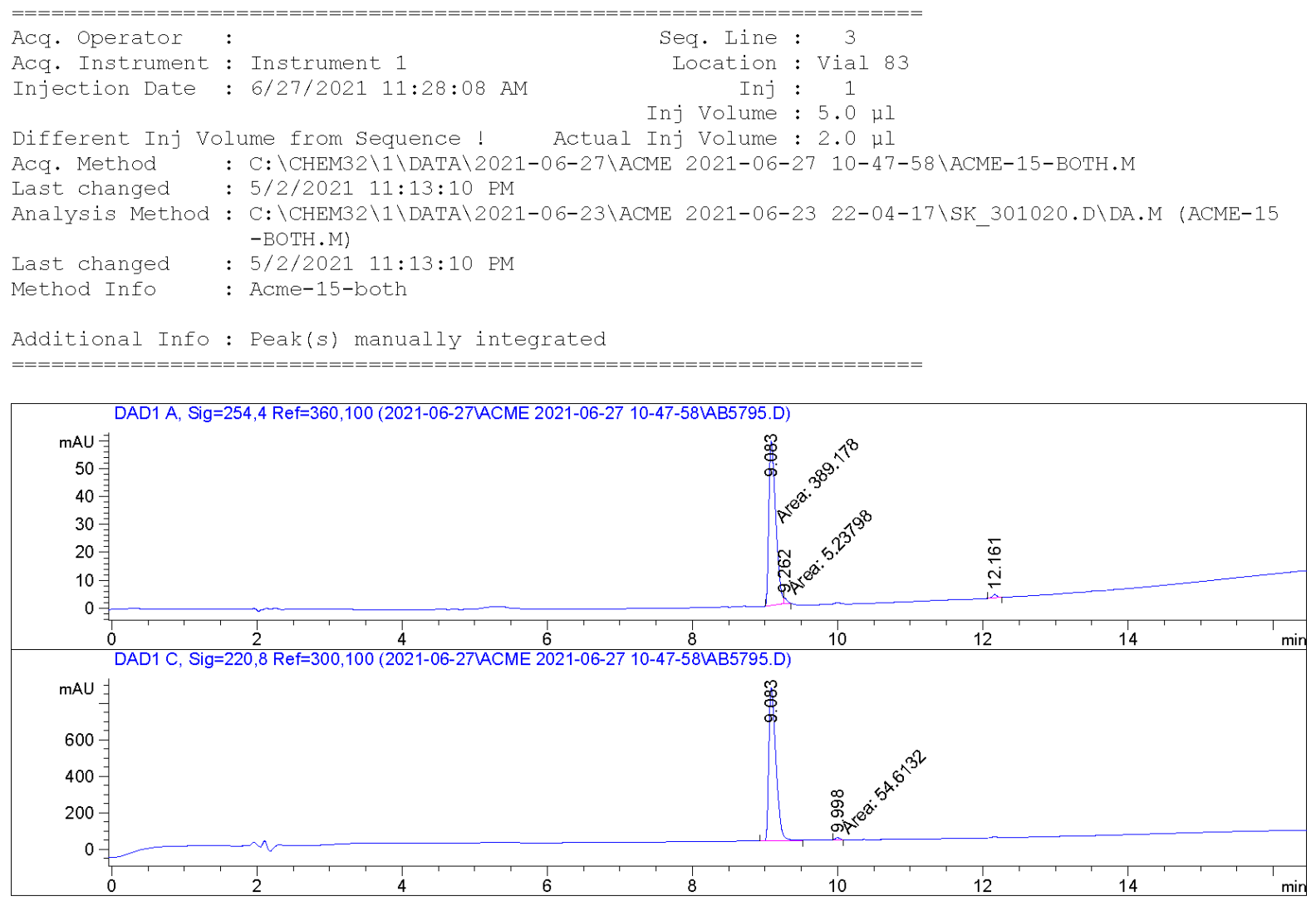

Area Percent Report

\begin{tabular}{|c|c|c|c|c|}
\hline Sorted By & $:$ & Signal & & \\
\hline Multiplier & $:$ & 1.0000 & & \\
\hline Dilution & : & 1.0000 & & \\
\hline Use Multiplier \& & Dilution & Factor with & ISTDS & \\
\hline \multicolumn{5}{|c|}{ Signal 1: DAD1 A, Sig=254, 4 Ref $=360,100$} \\
\hline $\begin{array}{c}\text { Peak RetTime Type } \\
\# \quad[\text { min] }\end{array}$ & $\begin{array}{l}\text { Width } \\
{[\min ]}\end{array}$ & $\begin{array}{c}\text { Area } \\
{[\mathrm{mAU} * \mathrm{~s}]}\end{array}$ & $\begin{array}{l}\text { Height } \\
\text { [mAU] }\end{array}$ & $\begin{array}{c}\text { Area } \\
\frac{\circ}{0}\end{array}$ \\
\hline \multicolumn{5}{|c|}{$----|-------|----|-------|----------\mid$} \\
\hline $1 \quad 9.083 \mathrm{MM}$ & 0.1099 & 389.17850 & 59.03827 & 97.2484 \\
\hline $9.262 \mathrm{MM}$ & 0.0426 & 5.23798 & 2.04850 & 1.3089 \\
\hline $3 \quad 12.161 \mathrm{BB}$ & 0.0724 & 5.77366 & 1.23736 & 1.4427 \\
\hline
\end{tabular}

Totals : $\quad 400.19014 \quad 62.32412$ 
Compound 7

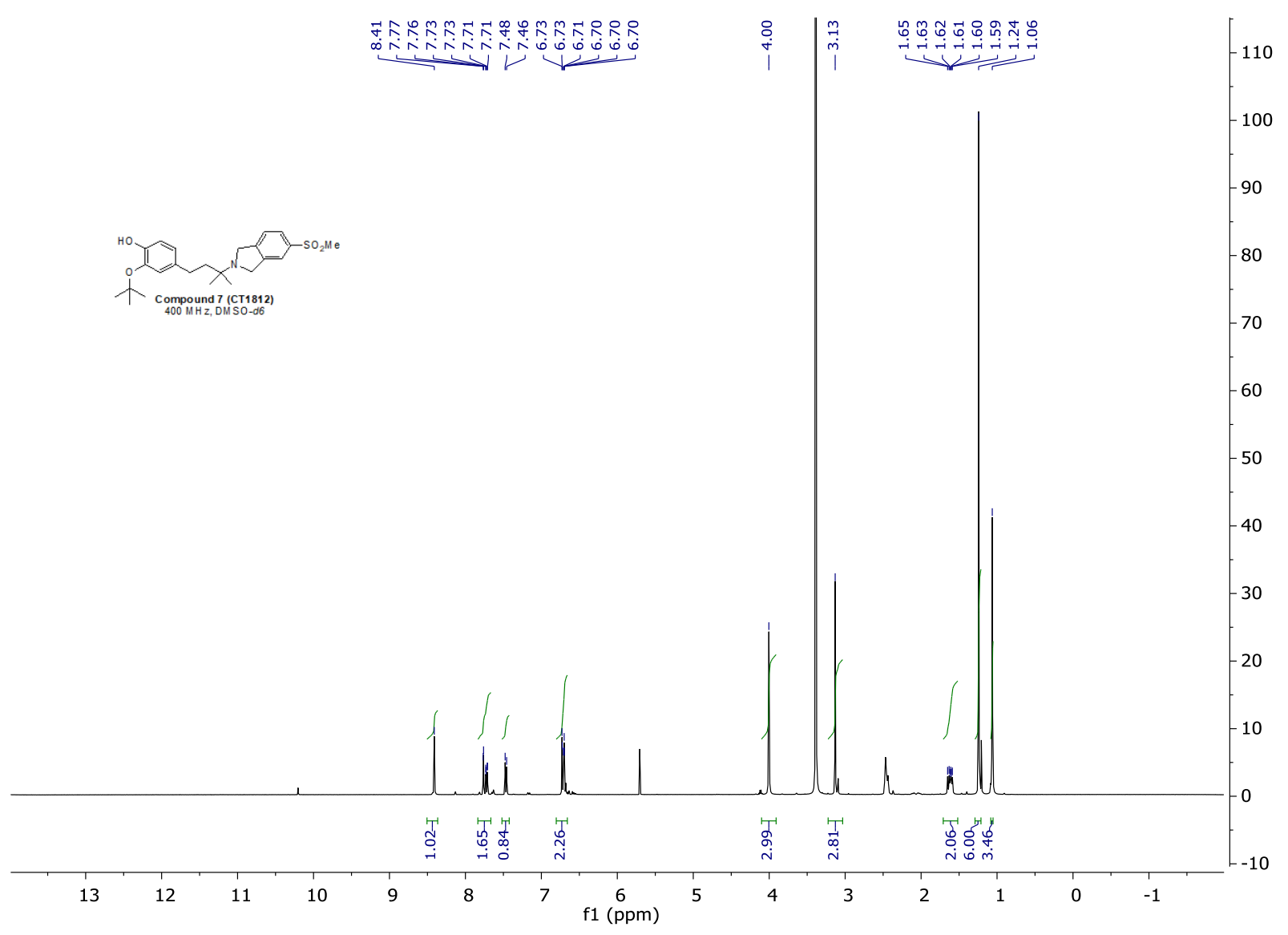




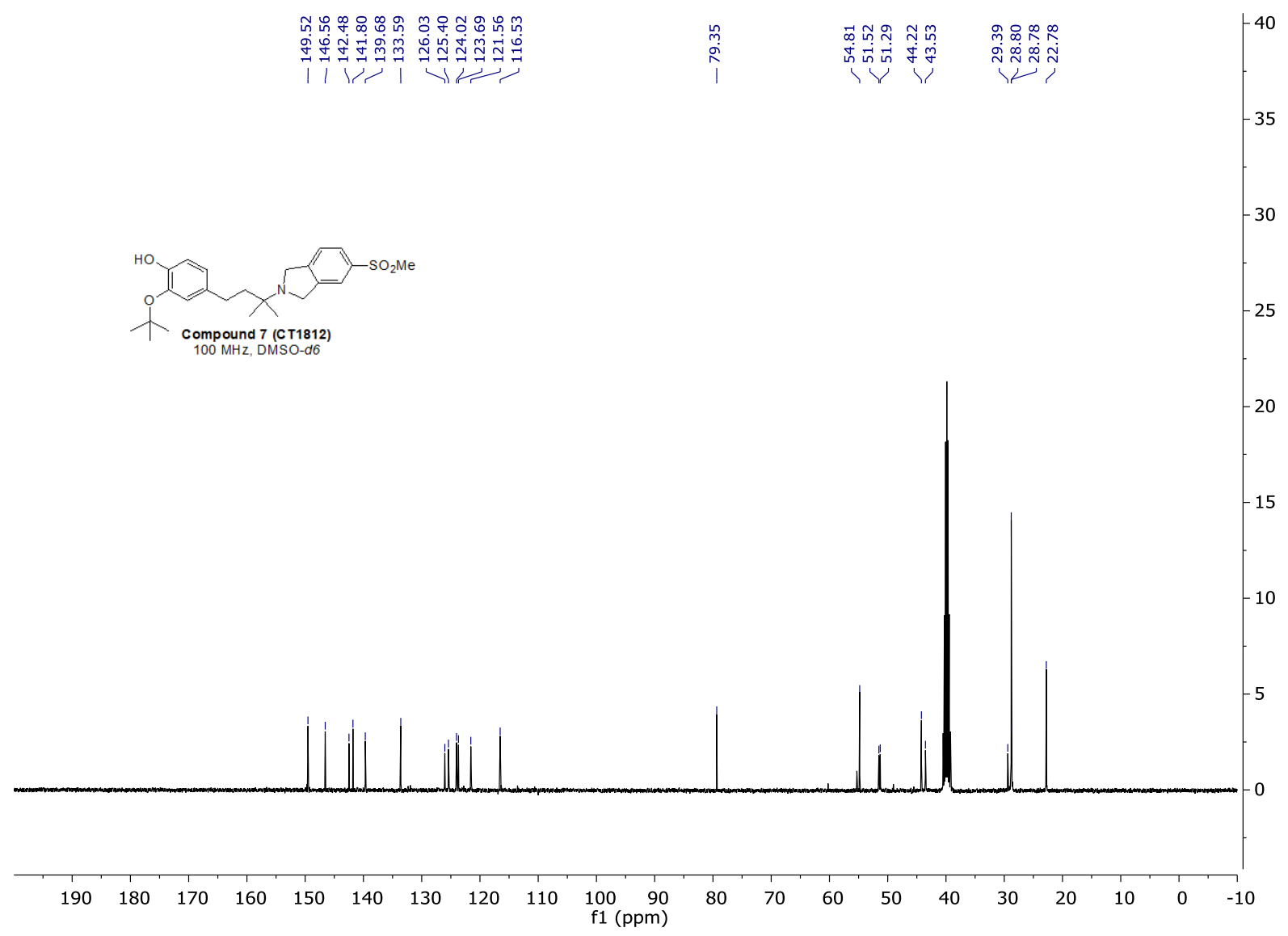




\section{Acme Bioscience, Inc. LC-MS Report}

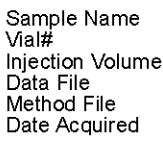

$\mathrm{mV}$

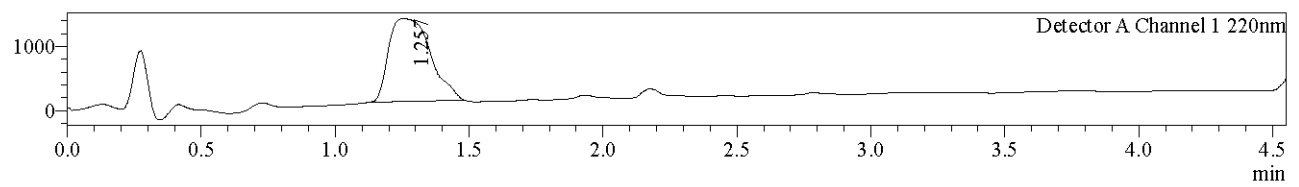

$\mathrm{mV}$

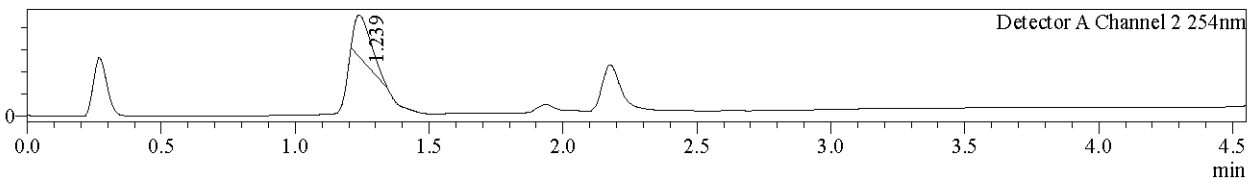

1 Det.A Ch1/220nm

2 Det.A Ch2 / $254 \mathrm{~nm}$

Detector A Channel 1 220nm
\begin{tabular}{|r|r|r|c|c|c|c|c|}
\hline Peak\# & Ret. Time & Area & Height & Conc. & Unit & Mark & Name \\
\hline 1 & 1.257 & 13878403 & 1290350 & 100.000 & & M & \\
\hline Total & & 13878403 & 1290350 & & & & \\
\hline
\end{tabular}

Detector A Channel $2254 \mathrm{~nm}$

Detector A Channel $2254 \mathrm{~nm}$
\begin{tabular}{|r|r|r|r|r|r|r|r|}
\hline Pcak\# & Ret. Time & Arca & Hcight & Conc. & Unit & Mark & Name \\
\hline 1 & 1.239 & 391937 & 92689 & 100.000 & & M & \\
\hline Total & & 391937 & 92689 & & & & \\
\hline
\end{tabular}

MS Spectrum Graph

Line\#:1 R.Time:1.267(Scan\#:77)

MassPeaks:985

Spectrum Mode:Single 1.267(77) BasePeak:432.35(4827192)

BG Mode:None Segment 1 - Event 1

ESI Positive

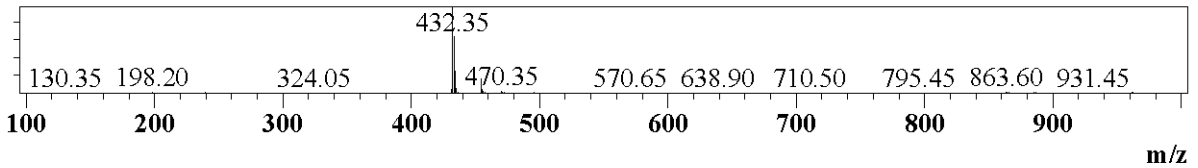

Line\#:2 R.Time:1.283(Scan\#:78)

MassPeaks: 1003

Spectrum Mode:Single 1.283(78) BasePeak:249.05(229973)

BG Mode:None Segment 1 - Event 2

ESI Negative

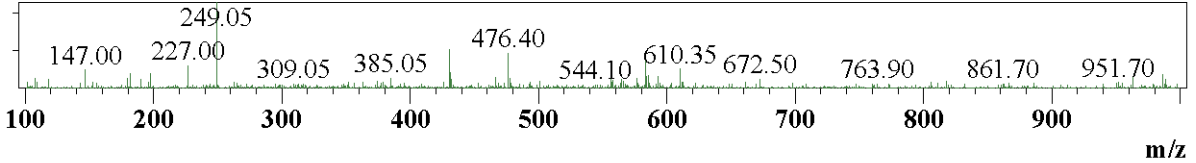




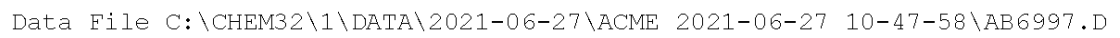
Sample Name: AB6997
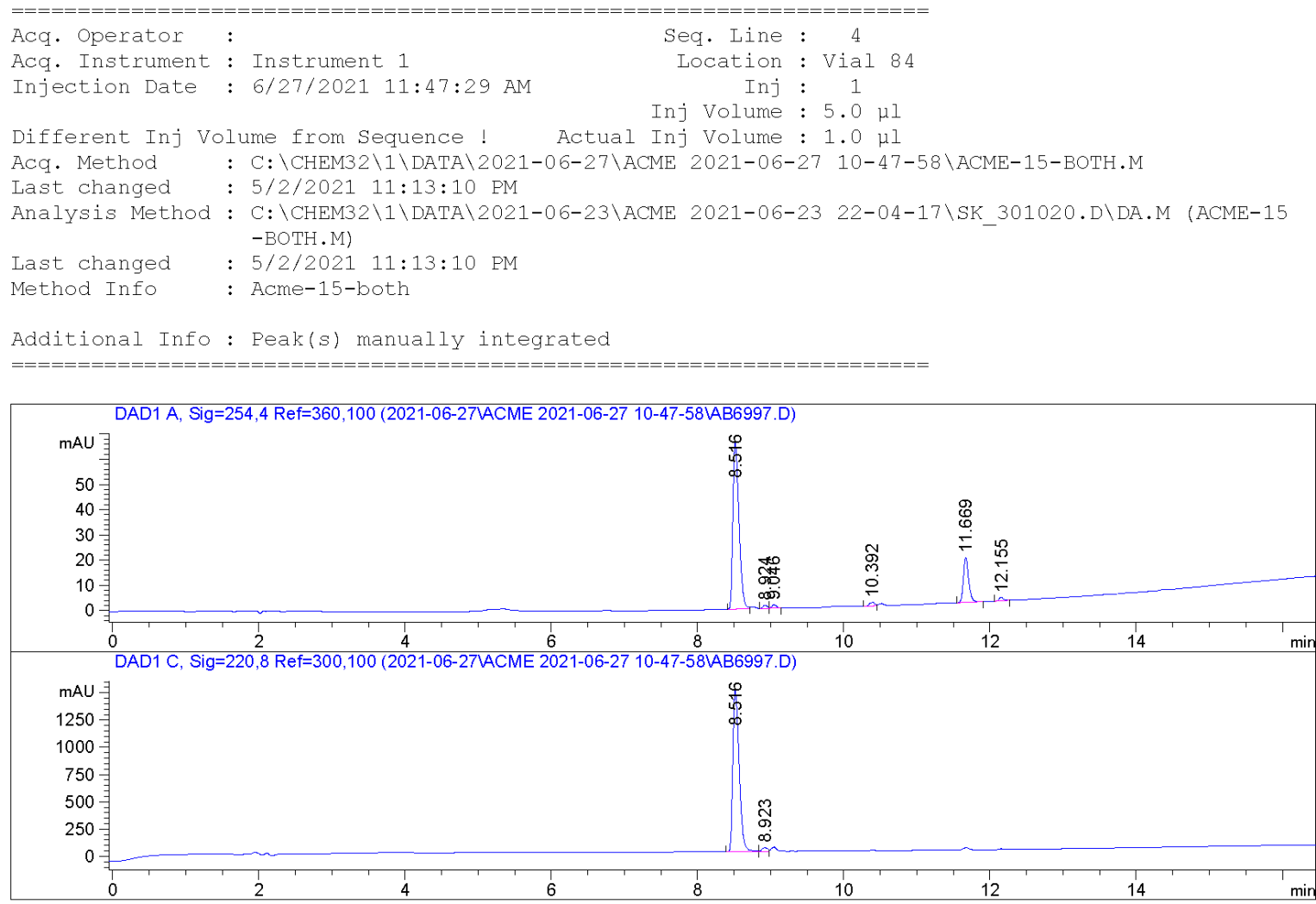

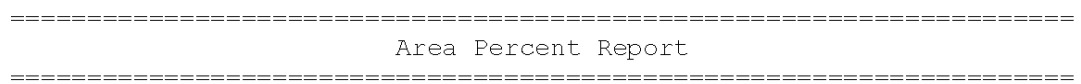

Sorted By : : Signal

Multiplier : : 1.0000

Dilution $\quad: \quad 1.0000$

Use Multiplier \& Dilution Factor with ISTDs

Signal 1: DAD1 A, Sig=254,4 Ref=360, 100

\begin{tabular}{|c|c|c|c|c|c|c|}
\hline $\begin{array}{c}\text { Peak } \\
\#\end{array}$ & $\begin{array}{c}\text { RetTime } \\
\text { [min] }\end{array}$ & Type & $\begin{array}{c}\text { width } \\
\text { [min] }\end{array}$ & $\begin{array}{c}\text { Area } \\
{\left[\mathrm{mAU}{ }^{*} \mathrm{~s}\right]}\end{array}$ & $\begin{array}{l}\text { Height } \\
\text { [mAU] }\end{array}$ & $\begin{array}{c}\text { Area } \\
\frac{\circ}{\partial}\end{array}$ \\
\hline \multicolumn{7}{|c|}{$----|-------|$} \\
\hline 1 & 8.516 & BV & 0.0887 & 379.37027 & 66.37409 & 76.9625 \\
\hline 2 & 8.924 & $\mathrm{BV}$ & 0.0675 & 5.15979 & 1.21517 & 1.0468 \\
\hline 3 & 9.046 & $\mathrm{VB}$ & 0.0676 & 5.98769 & 1.35412 & 1.2147 \\
\hline 4 & 10.392 & BV & 0.0803 & 7.79820 & 1.50831 & 1.5820 \\
\hline 5 & 11.669 & $\mathrm{BB}$ & 0.0740 & 88.65919 & 17.84025 & 17.9862 \\
\hline 6 & $12 \cdot 155$ & $\mathrm{BB}$ & 0.0734 & 5.95345 & 1.25366 & 1.2078 \\
\hline Tot & $:$ & & & 492.92859 & 89.54559 & \\
\hline
\end{tabular}

